\title{
Exploring the connection between indigenous peoples' human rights and international environmental law ${ }^{1}$
}

\author{
Mario Alejandro Delgado GalárragA ${ }^{\star 2}$ \\ Universidad Metropolitana, Ecuador
}

\begin{abstract}
The paper reviews whether Indigenous Peoples' worldview has directly influenced or not the decisions made by the Inter-American Court of Human Rights related exclusively to their human and environmental rights.

In the first section of the investigation, it is described the main aspects to take into consideration regarding Indigenous Peoples and international law; i.e. conceptualization of the term Indigenous Peoples, its evolution in international law, and their core rights. Then, the text will deal with the relationship between Human Rights Law and International Environmental Law, through the discussion of how human rights have been included in the context of international environmental law. Afterwards, the study will explore the close bond that exists between indigenous peoples and the environment, by relating to the different conceptions of its features according to them. Finally, the paper will analyse the decisions taken by the Inter-American Court of Human Rights in cases related to indigenous peoples' environmental issues. The conclusion will lead to determine the contribution of human rights and international environmental law to solve indigenous peoples'controversies and vice versa.
\end{abstract}

KEYWORDS Indigenous peoples, international environmental law, Human Rights, nature's rights, Inter-American court of Human Rights.

* Máster en Derecho del Medio Ambiente Global y Cambio Climático LLM, por la Universidad de Edimburgo (University of Edinburgh)

1. The paper draws on my dissertation for the degree of LLM at Edinburgh Law School, 2016/17.

2. LLM in Global Environment and Climate Change Law. Assistant Professor, School of Law, Universidad Metropolitana del Ecuador. madelgadoga@hotmail.com 


\section{Introduction}

Indigenous peoples (which will here be referred to as IP) are considered as a vulnerable group in international law, mainly because of their lack of power and their inability to make use of their rights or to prevent its violations. ${ }^{3}$ This issue is accompanied by the increasing need of a globalized world to obtain economic benefits through the exploitation of natural resources, which mainly are found within their lands ${ }^{4}$.

In addition, as noted by Anaya, '[h]istorical phenomena grounded on racially discriminatory attitudes are not just blemishes of the past but rather translate into current inequities; ${ }^{\prime}$ which demonstrates that IP's rights violations have not been completely exterminated since colonial times. In fact, these abuses explain the current organization of the world as part of the modernity's agenda ${ }^{6}$.

However, IP have been gaining a significant place in international law during the last decades. Human Rights Law (HHRR) has played a leading role regarding the development of their rights. Furthermore, according to IP's culture and customs, their ancestral worldview, which exposes their relationship with the environment, is an essential issue to consider when dealing with matters that might concern them ${ }^{7}$. Hence, contrasting HHRR and International Environmental Law (IEL) will determine the contribution of these topics to the realization of IP's rights.

In this context, the main subject, to be debated throughout this study, will focus on how IP's rights have developed in the international arena, mainly regarding environmental themes; and whether IP's cosmovision has influenced, implicitly, in Court decisions. Hence, it will be indispensable to narrow the discussion and centre it within the Inter-American Court of Human Rights' (IACrtHR) contribution.

The IACrtHR influence is of great consideration, as it has widened the participation of IP in the international arena; its awards' evolution demonstrates the importance given now by international law to IP. Therefore, the Court's case-law will portray whether it has taken into account IP's worldview regarding the environment or it has dealt in a superficial way IP's environmental beliefs.

3. INTERNATIONAL LABOUR OFFICE (1989) p. xi.

4. KINGSBURY, (2011) p. 545.

5. ANAYA (2004) p. 4.

6. ACOSTA (2013) p. 38.

7. PORTAL OF CULTURE OF LATIN AMERICA AND THE CARIBBEAN, 'Kari-Oca Declaration and Indigenous Peoples' Earth Charter' (2016) www.lacult.unesco.org/doccult/listado.php?uid_ ext=\&getipr $=\& \lg =2$ accessed 26 March 2018, Preamble. 


\section{IP and International Law}

A wide range of IP exists around the world; they vary in identities and names. For example, the Inuit in the Artic, the Maasai in Africa, the Mayas in North and Central America, the Mapuches in Chile, the Huaorani in Ecuador, and the Saami in Northern Europe, to name a few ${ }^{8}$. IP have different characteristics and features, hence, defining each of them will be a challenging task; resultantly, a general definition within the framework of international law will be considered for purposes of this study. Furthermore, the evolution of IP's rights within the international field will disclosure their long ongoing struggles ${ }^{9}$. The prior aspects are essential to understand their surrounding context.

\subsection{Conceptualizing IP}

The term 'indigenous peoples' does not find an authoritative definition under international law; ${ }^{10}$ consequently, several international instruments attempted defining IP by assigning specific features to them. For purposes of this research, the term IP will cover terms such as tribal ${ }^{11}$ and aboriginal, ${ }^{12}$ as they are commonly used in the international field.

The International Labour Organization's Convention Concerning Indigenous and Tribal Peoples in independent countries (ILO 169) identifies IP as "peoples in independent countries who are regarded as indigenous on account of their descent from the populations which inhabited the country, or a geographical region to which the country belongs, at the time of conquest or colonisation or the establishment of present state boundaries and who, irrespective of their legal status, retain some or all of their own social, economic, cultural and political institutions." ${ }^{13}$

8. For an extended list see INTERCONTINENTal CRY (2017) https://intercontinentalcry.org/ indigenous-peoples accessed 26 March 2018.

9. ANAYA (2004) p. 3.

10. UNITED NATIONS (2009) p. 4.

11. Convention concerning the Protection and Integration of Indigenous and Other Tribal and Semi-Tribal Populations in Independent Countries (ILO No 107) (1959); Convention Concerning Indigenous and Tribal Peoples in Independent Countries (ILO No 169) (1991).

12. International Convention for the Regulation of Whaling (1948), Schedule, para 13.

13. Convention Concerning Indigenous and Tribal Peoples in Independent Countries (ILO № 169) (1991) art. 1(1)(b). 
As well, the Special Rapporteur of the Sub-Commission on Prevention of Discrimination and Protection of Minorities, José Martínez Cobo, in his Study on the Problem of Discrimination against Indigenous Populations (Martínez Cobo Report), defined the term IP. It noted that IP are those that, possessing a historical continuity, consider themselves diverse from the prevailing sectors of the society; they are determined to preserve, develop and transmit to future generations their ancestral culture, in conformity with their own cultural, social and political systems ${ }^{14}$.

Although IP have ascertained that a conceptualization is 'not necessary nor desirable, ${ }^{15}$ they submitted a resolution to the Working Group on Indigenous Populations that contained a definition: "We, the Indigenous Peoples [...], have reached a consensus on the issue of defining Indigenous Peoples [...]. We categorically reject any attempts that Governments define Indigenous Peoples. We further endorse the Martínez Cobo report [...] in regard to the concept of 'indigenous'. Also, we acknowledge the conclusions and recommendations by Chairperson-Rapporteur Madame Erica Daes in her working paper on the concept of indigenous peoples. ${ }^{16}$ This contribution is remarkable as it represents the views of how IP may look at themselves; and it legitimizes the content of the reports mentioned. ${ }^{17}$

Yet, standardizing the term is deemed problematic, as its accuracy will differ between different IP groups and countries. ${ }^{18}$ For instance, for some groups, it will be more accurate to centre the discussion using the term "local communities" rather

14. UNITED NATIONS (2009), p. 4.

15. UNITED NATIONS ECONOMIC AND SOCIAL COUNCIL (1996a) para. 35.

16. UNITED NATIONS ECONOMIC AND SOCIAL COUNCIL (1996b) para. 31.

17. The Martinez-Cobo definition expressed: "Indigenous communities, peoples and nations are those which, having a historical continuity with pre-invasion and pre-colonial societies that developed on their territories, consider themselves distinct from other sectors of the societies now prevailing in those territories, or parts of them. They form at present non dominant sectors of society and are determined to preserve, develop and transmit to future generations their ancestral territories, and their ethnic identity, as the basis of their continued existence as peoples, in accordance with their own cultural patterns, social institutions and legal systems". While Daes definition relied on IP factors: "(a) Priority in time, with respect to the occupation and use of a specific territory; (b) The voluntary perpetuation of cultural distinctiveness, which may include the aspects of language, social organization, religion and spiritual values, modes of production, laws and institutions; (c) Self-identification, as well as recognition by other groups, or by State authorities, as a distinct collectivity; and (d) An experience of subjugation, marginalization, dispossession, exclusion or discrimination, whether or not these conditions persist."

18. KINGSBURY (1998) p. 414; UNITED NATIONS (2009) p. 6. 
than "indigenous peoples"19 since the latter could be conceived as "underinclusive or inequitable. ${ }^{\prime 2}$ As well, for some African ${ }^{21}$ and Asian ${ }^{22}$ States, conceptualizing IP 'does not accurately capture identities and outlooks in some regions not structured by waves of recent invasion and migration.'.23

This argument becomes evident by observing that ILO 169 was ratified by mainly American countries ${ }^{24}$. However, the issue disappears "if we think of "indigenous" peoples as groups which are native to their own particular ancestral territories within the borders of the existing State, rather than persons that are native generally to the region in which the State is located.'.25

While neither treaties nor case-law ${ }^{26}$ have set a precise definition of IP, its conceptualization will identify who is considered part of an IP group; which will lead to the entitlement of specific rights ${ }^{27}$. According to the current debate amongst scholars, different conclusions have been reached about the definition of $\mathrm{IP}^{28}$. However, in the current research, it will be considered the one included in the Martínez Cobo Report, since IP's groups have endorsed it, and its main criteria will contribute in unravelling the current analysis.

\subsection{IP's Evolution in International Law}

In Modern Era, statehood is a fundamental principle in International Public Law; ${ }^{29}$ consequently, States are the centre of international legal discourse. ${ }^{30}$ However, the re-

19. Op. cit., pp. 450-453.

20. Op. cit., p. 451.

21. BARELLI (2010) p. 958; GILBERT (2011) pp. 249-254; ERUETI (2011) p. 119.

22. THORNBERRY (2002) p. 38.

23. KINGSBURY (1998) p. 456.

24. INTERNATIONAL LABOUR OFFICE (2017) www.ilo.org/dyn/normlex/en/f?p=NORMLEXP UB:11300:0::NO::P11300_INSTRUMENT_ID:312314 accessed 26 March 2018.

25. UNITED NATIONS ECONOMIC AND SOCIAL COUNCIL (1996a) para. 64. 26. PHILLIPS (2015) p. 120.

27. KINGSBURY (1999) p. 337; KINGSBURY (1998) p. 414.

28. THORNBERRY (2002) pp. 33-61; KINGSBURY (1998); KINGSBURY (1999); KINGSBURY (2001) pp. 189-252; BARELLI (2010) pp. 957-959, 971-972; GILBERT (2011); ERUETI (2011); FIRESTONE et al. (2005) pp. 223-231; BARSH (2008) pp. 830-833; SIEGFRIED (1999) pp. 57-128; GILLESPIE (2001b) pp. 89-99.

29. For a broader discussion, see CRAWFORD (2012) pp. 115-165; HILLIER (1999) pp. 75-107; Statute of the International Court of Justice (1945) art. 59.

30. ANAYA (2004) p. 49. 
cognition of new States became a crucial aspect, ${ }^{31}$ as most of those States are in Africa, America, and Asia; thus, it was palpable the intromission of new nonEurocentric cultures to international law's mainstream ${ }^{32}$.

Although '[i]nternational law is, for the time being, still primarily applicable to States, ${ }^{33}$ its development has resulted in a more inclusive attitude, ${ }^{34}$ since focusing only in States misled the current practice ${ }^{35}$. Individuals and groups ${ }^{36}$ are now subjects of international law, mainly in topics relating to HHRR and investment protection ${ }^{37}$. Concerning IP, ${ }^{38}$ they have a 'unique position in the world and have sought to have their status and rights given effect under international law.'39 They are no longer considered as "objects", and they have become important participants in the law-making arena $^{40}$. The gaining international moment has led to include IP's rights within broader aspects, such as climate change, sustainable development, and environmental protection $^{41}$.

In this context, the first multilateral treaty regarding IP's rights was the ILO Convention 107; which aimed to include IP in their respective countries' life ${ }^{42}$ and to ensure their equal rights within the society. ${ }^{43}$ Since ILO 107, IP have been participating permanently in the United Nations (UN) and in the Organization of American States (OAS) forums. ${ }^{44}$

31. Op. cit., p. 50.

32. Ibid.

33. HIGGINS (1994) p. 39; see also Statute of the International Court of Justice (1945) art. 38(1); Vienna Convention on the Law of Treaties (1980) art 2(1)(a).

34. CRAWFORD (2012) pp. 116-126.

35. BOYLE and CHINKIN (2007) p. 41. 36. ANAYA (2004), p. 53.

37. CRAWFORD (2012) p. 121; ANAYA (2004) p. 52.

38. For a historical summary see Inter-American Commission on Human Rights, 'The Human Rights Situation of the Indigenous People in the Americas,' (20 October 2000) Doc. OEA/Ser.L/V/ II.108, Doc. 62.

39. BOYLE and CHINKIN (2007) p. 48.

40. Ibid.; KINGSBURY (1998) pp. 440-441.

41. INTERNATIONAL LABOUR OFFICE (1989) p. xii.

42. Convention concerning the Protection and Integration of Indigenous and Other Tribal and Semi-Tribal Populations in Independent Countries (ILO No 107) (1959) art. 2.

43. Ibid, art. 3.

44. ANAYA (2004) p. 56-57; see also UNITED NATIONS ECONOMIC AND SOCIAL COUNCIL (2000). 
Afterwards, the adoption of ILO 169, as the cornerstone of IP's rights evolution in international law, 45 because of its binding nature, became 'part of a larger body of developments that can be understood as giving rise to new customary international law with the same normative thrust.' ${ }^{46}$ Since ILO 169, IP's rights were considered in plenty of UN resolutions; ${ }^{47}$ as well as, in various international instruments regarding their rights $^{48}$. Although some of these instruments are in the form of soft-law ${ }^{49}$, they can support the evolution of international customary law or general principles of law ${ }^{50}$.

Finally, the United Nations Declaration on the Rights of Indigenous Peoples (UNDRIP) is considered as 'an authoritative statement of norms concerning IP on the basis of generally applicable human rights principles. ${ }^{51}$ Moreover, it reflects the colonisation prejudices that IP have suffered ${ }^{52}$, the deprivation of lands and resources, and the denial of their right to self-determination ${ }^{53}$. Furthermore, UNDRIP emphasises the right to self-determination ${ }^{54}$, and it covers matters regarding land and resources ${ }^{55}$; it also served as the starting point for the adoption of the American Declaration on the Rights of Indigenous Peoples (ADRIP).

\subsection{IP's Core Rights}

Self-identification and self-determination are fundamental to understand the definition of IP. The former determines, individually or collectively, who can be considered part of an IP group; while the latter establishes how people decide on their own future

45. For a broader debate about ILO 169's process of adoption, see ANAYA (2004) pp. 58-61.

46. Op. cit., p. 61.

47. Op. cit., pp. 58-65.

48. United Nations Declaration on the Rights of Indigenous Peoples (2007); American Declaration on the Rights of Indigenous Peoples (2016); Convention on the Rights of the Child (1990); Rio Declaration on Environment and Development (1992); United Nations (1992); Convention on Biological Diversity (1993).

49. BOYLE and CHINKIN (2007) pp. 212-213. 50. PHILLIPS (2015) p. 120.

51. ANAYA (2004) p. 65.

52. HITCHCOCK (1994) p. 5; See also UNITED NATIONS DECLARATION ON THE RIGHTS OF INDIGENOUS PEOPLES (2007) preamble; AMERICAN DECLARATION ON THE RIGHTS OF INDIGENOUS PEOPLES (2016) preamble.

53. BURGER (2011) p. 43.

54. UNITED NATIONS DECLARATION ON the RIGHTS OF INDIGENOUS PEOPLES (2007) art. 3.

55. Op. cit., arts. 25-29. 
and resources. Both rights should not be confused ${ }^{56}$. However, for the purpose of the present investigation; only self-determination will be reviewed.

\subsubsection{Self-determination}

The right to self-determination can be considered as a contentious issue; ${ }^{57}$ its general connotations ${ }^{58}$ will be discussed so to understand its implications with IP. Additionally, regarding internal and external self-determination ${ }^{59}$, this research will refer only to the former as IP have been seeking for it, rather than independence from their States $^{60}$.

Self-determination has been included in various international instruments ${ }^{61}$. The UN Charter established that the right to self-determination is one of UN purposes ${ }^{62}$; moreover, both the ICCPR and the ICESCR affirm that '[a]ll peoples have the right of self-determination ${ }^{\prime 63}$ and they can determine their political, economic, social and cultural development ${ }^{64}$. Additionally, the nature of this right is 'to be in control of their

56. UNITED NATIONS ECONOMIC AND SOCIAL COUNCIL (1996b) para 42.

57. ZYBERI (2009) p. 430.

58. For a broader discussion about self-determination see ANAYA (1993) pp. 131-164; HANNUM (1990) pp. 27-49; CRAWFORD (2006) pp. 107-131; CASSESE (1995); SHELTON (2011) pp. 60-81.

59. For an extensive discussion on internal and external self-determination see ANAYA (2004) pp. 105-106; SHELTON (2011) pp. 64-71; HIGGINS (2009) p. 830; SARANTI (2012) pp. 446-450; MCCORQUODALE (1994) pp. 863-865; SUMMERS (2013) pp. 229-249.

60. SHELTON (2011) p. 62.

61. UNITED NATIONS CHARTER (1945) art. 1(2); International Covenant on Civil and Political Rights (1976) arts. 1, 27; International Covenant on Economic, Social and Cultural Rights (1976) art 1; African Charter on Human and Peoples' Rights (1986) art. 20; United Nations Declaration on the Rights of Indigenous Peoples (2007) arts. 3-5; American Declaration on the Rights of Indigenous Peoples (2016) arts. 3, 21-22; Convention Concerning Indigenous and Tribal Peoples in Independent Countries (ILO No 169) (1991) art. 1.

62. UNITED NATIONS CHARTER (1945) art. 1(2). For a discussion relating the use of the term peoples see: ANAYA (2004) p. 100-103.

63. International Covenant on Civil and Political Rights (1976) art. 1; International Covenant on Economic, Social and Cultural Rights (1976) art. 1.

64. International Covenant on Civil and Political Rights (1976) art. 1; International Covenant on Economic, Social and Cultural Rights (1976) art. 1. 
own destinies under conditions of equality', 65 including a 'standard of governmental legitimacy within the modern human rights frame. ${ }^{66}$

In this respect, the International Court of Justice (ICJ) advisory opinion in the Western Sahara case defined self-determination as 'the freely expressed will of peoples,'67 further, it determined two requirements to its implementation: its declaration should be free and genuine ${ }^{68}$, without external interference, and it must represent the will of the people concerned. ${ }^{69}$

As well, in the East Timor case and the Palestinian Wall case the ICJ considered the right to self-determination of an erga omnes character $;^{70}$ which means that it can be enforceable by any State ${ }^{71}$. The erga omnes obligations were already examined by the ICJ in the Barcelona Traction case; in which the Court stated that they 'derive [...] from the principles and rules concerning the basic rights of the human person; ${ }^{72}$ hence, the ICJ has recognised self-determination as part of fundamental human rights.

\subsubsection{IP and Self-determination}

The UNDRIP and the ADRIP have expressly recognised self-determination as part of IP's human rights. ${ }^{73}$ Moreover, the Committee on Economic, Social, and Cultural Rights has sustained that self-determination is assured to IP $;^{74}$ which was likewise endorsed by the IACrtHR, concluding that IP are entitled to the right to self-determination. ${ }^{75}$

65. ANAYA and WILLIAMS (2001) p. 78.

66. James Anaya (2004) p. 104.

67. Western Sahara (Advisory Opinion) [1975] ICJ Rep, p. 12, para 59.

68. Op. cit., para 55.

69. ZYBERI (2009) p. 438.

70. East Timor (Portugal v. Australia) (Judgement) [1995] ICJ Rep, p. 90, para 29. (Hereinafter East Timor case).

71. International Law Commission Report (2001). See also Legal Consequences of the Construction of a Wall in the Occupied Palestinian Territory (Advisory Opinion) [2004] ICJ Rep, p. 136, para 88.

72. The Barcelona Traction, Light and Power Company, Limited (Belgium v Spain) (Judgment) [1970] ICJ Rep, p. 3, paras. 32-34.

73. United Nations Declaration on the Rights of Indigenous Peoples (2007) art. 3-5; American Declaration on the Rights of Indigenous Peoples (2016) art. 3.

74. UNITED NATIONS COMMITTEE ON ECONOMIC, SOCIAL AND CULTURAL RIGHTS (2003) para 11.

75. Case of the Saramaka People v. Suriname, Merits, Reparations and Costs, Judgement, InterAmerican Court of Human Rights Series C No 172 (28 November 2007) para. 93. 
Considering the previous statements, the right to self-determination plays an important role while studying IP's rights and the environment ${ }^{76}$. It entails further rights that are closely related to them ${ }^{77}$, namely, the sovereignty over natural wealth and resources $^{78}$; which will further lead to the right to control their own lands, consultation and participation ${ }^{79}$, the right to development ${ }^{80}$, benefit-sharing, to undertake a prior environmental and social impact assessment ${ }^{81}$, and the right to free, prior, informed consent ${ }^{82}$, to name a few. As well, the foundation of these rights should be pursuant IP's spiritual traditions, cultures, histories, and philosophies ${ }^{8_{3}}$, which derive from their economic, political and social structures ${ }^{84}$. ADRIP ${ }^{85}$ and ILO $169^{86}$ took a similar approach within their provisions.

To conclude, the linking between self-determination, the environment and IP can be viewed as the entitlement that 'allows [them] to protect their traditional, landbased cultural practices regardless of whether they also possess the sovereign right to govern those lands or, in the case of climate change, prevent the practices that are jeopardizing those environments. ${ }^{87}$

76. ANAYA (2004) p. 97.

77. GROSS (1980) para. 59; see also KINGSBURY (2001) p. 231.

78. ZYBERI (2009) p. 439.

79. ANAYA and WILLIAMS (2001) p. 78.

80. United Nations Declaration on the Rights of Indigenous Peoples (2007) preamble. 81. SHELTON (2011) p. 76.

82. VERBEEK (2012) p. 265.

83. United Nations Declaration on the Rights of Indigenous Peoples (2007) preamble.

84. Ibid.

85. American Declaration on the Rights of Indigenous Peoples (2016), preamble.

86. Convention Concerning Indigenous and Tribal Peoples in Independent Countries (ILO № 169) (1991) arts. 6, 7, 15.

87. TSOSIE (2007) p. 1652. 


\section{IEL and Human Rights}

Despite being contemplated as a new field ${ }^{88}$, IEL has been gaining rapidly a major role in the international community ${ }^{89}$, not only regarding Court decisions; which have made use of the term ${ }^{90}$, but also it has considered as a sensitive topic by major international institutions, such as the United Nations.

For the purpose of the current investigation, IEL will be considered as the field of international law that 'encompass [its] entire corpus, public and private, relevant to environmental problems, ${ }^{91}$ with its own characteristic structure and process, and its own set of conceptual tools and methodologies ${ }^{92}$, However, it remains 'rooted in international law and draws upon much of its repertoire, such as the rules governing customary law, the law of treaties, the law of state responsibility, and jurisdictional rules.'93

On the other hand, human rights are intended to ensure the basic conditions needed for rights-holders to pursue their various goals;' ${ }^{\prime 4}$ which moved well beyond the individual scope, to a collective one, such is the case of IP ${ }^{95}$. In this respect, the former ICJ's Vice-President Judge Weeramantry, in his separate opinion on the Gabcikovo-Nagymaros case, stated that environmental protection is part of 'contemporary human rights doctrine, for it is a sine qua non for numerous human rights such as the right to health and the right to life itself. ${ }^{\prime 6}$ The close linkage between HHRR and IEL is reflected in environmental rights and in existing human rights that have been applied to attend environmental issues. Therefore, we can state that both human rights and environmental rights 'exist in order to promote self-realization and individual development.' ${ }^{97}$

88. BODANSKY et al. (2008).

89. SAND (2008) p. 30.

90. Gabcikovo-Nagymaros Project (Hungary v Slovakia) (Judgment) [1997] ICJ Rep, p. 7, para. 92; see also Iron Rhine Arbitration (The Kingdom of Belgium $v$ The Kingdom of Netherlands) (2005) PCA, para. 58; Pulp Mills on the River Uruguay (Argentina v. Uruguay) (Judgment) [2010] ICJ Rep, p. 14, para 57.

91. Op. cit., p. 2.

92. BODANSKY et al (2008) p. 5.

93. Op. cit., pp. 5-6.

94. MERRILLS (2008) p. 666.

95. For a complete reference see LEUPRECHT (2001) pp. 11-126; KINGSBURY (2001) pp. 189-252. 96. Gabcikovo-Nagymaros Project (Hungary v Slovakia) (Judgment) [1997] ICJ Rep, p. 7, Separate Opinion of Vice-President Weeramantry, p. 91 www.icj-cij.org/files/case-related/92/09219970925-JUD-01-03-EN.pdf accessed 26 March 2018. 


\subsection{Evolution of IEL with a Human Rights Approach}

The emergence of environmental problems, mainly caused by human activity, raised the need of IEL to face them; which was materialised since 'environmental issues are accompanied by a recognition that ecological interdependence does not respect national boundaries and that issues previously considered to be matters of domestic concern have international implications. ${ }^{98}$ However, as its evolution can be extensi$\mathrm{ve}^{99}$, the current section will discuss mainly the development of IEL regarding HHRR approaches.

Various international legal cases contributed significantly to the evolution of IEL in early stages, mainly in areas concerning living resources in the global commons ${ }^{100}$; cross-border air pollution ${ }^{101}$; and transboundary watercourses ${ }^{102}$; which have supported IEL throughout its life ${ }^{103}$. As well, in early stages, various environmental treaties involved topics such as fisheries ${ }^{104}$, living resources ${ }^{105}$, and conservation of species ${ }^{106}$. These treaties 'only resulted in very sporadic and selective contractual agreements with limited regulatory effect; ${ }^{107}$ mainly, they focused on States parties' commercial interests, with a minor contribution to environmental protection ${ }^{108}$.

98. SANDS (2012) p. 3.

99. For an extensive review see BODANSKY et al (2008); SAND (2008); SANDS (2012) pp. 25- 69; BIRNIE et al. (2009) pp. 2-12, 43-105; BEYERLIN and MARAUHN (2011) pp. 1-30; BODANSKY (2011) pp. 18-36.

100. Behring Sea Fur Seals Arbitration, Moore, 1 Int Arb Awards (1898) 755, repr in 1 IELR (1999). 101. Trail Smelter Case (United States of America v Canada) (1941) 35 AJIL 684.

102. Lake Lanoux Arbitration (France v. Spain) (1957) 12 R.I.A.A. 281.

103. BIRNIE et al. (2009) p. 38.

104. See the Agreement relating to the International Convention for regulating the police of the North Sea Fisheries (1884); Convention for the Preservation of the Halibut Fishing of the Northern Pacific (1924).

105. See the Convention for the Preservation and Protection of Fur Seals (1911); Convention for the Regulation of Whaling (1935); International Convention for the Regulation of Whaling (1948). 106. See the Convention for the Preservation of Wild Animals, Birds and Fish in Africa (1900); Convention on the Preservation of Flora and Fauna in Their Natural State (1936).

107. BEYERLIN and MARAUHN (2011) p. 4.

108. Ibid; SAND (2008) p. 5. 
Regarding IEL and HHRR, at early stages, two African-related treaties reflected the attention of colonial empires to guard their resources located abroad ${ }^{109}$, leaving aside IP's interests: the 1900 Convention for the Preservation of Wild Animals, Birds and Fish in Africa ${ }^{110}$ (which never entered into force) ${ }^{111}$, and the 1933 Convention on the Preservation of Flora and Fauna in their Natural State ${ }^{112}$. Both treaties were adopted by colonial power parties, and were applied only to their African colonies ${ }^{113}$; their purpose was the preservation of endangered African species ${ }^{114}$.

The 1933 treaty intended to control IP's activities ${ }^{115}$; they were 'barred from hunting, while in national parks they were excluded altogether, forcibly dispossessed of their land if it fell within the boundaries of a designated sanctuary.' ${ }^{116}$ In IEL's dawn, thus, IP were not conceived as essential subjects who could play at the centre of the discussions regarding the global environment.

Subsequently, IEL evolved from a state-centred period ${ }^{117}$ to a more human rightsinclusive stage, since both 'were the most celebrated and pursued non-economic interests of the late twentieth century.'118 The evolution of HHRR in IEL resulted in the adoption of the Declaration of the United Nations Conference on the Human Environment (Stockholm Declaration), which stated the need of human beings for 'an environment of a quality that permits a life of dignity and well-being.' ${ }^{119}$ It did not recognise a right to a clean environment, although it linked existing human rights with the environment, by establishing that 'the exercise of other human rights indispensably requires basic environmental health., ${ }^{120}$

109. BODANSKY et al (2008) p. 2.

110. Convention for the Preservation of Wild Animals, Birds and Fish in Africa (1900).

111. MICKELSON (2001) p. 58.

112. Convention on the Preservation of Flora and Fauna in Their Natural State (1936).

113. MICKELSON (2001) p. 58.

114. Op. cit., pp. 58-59.

115. Op. cit., p. 59. See also Convention on the Preservation of Flora and Fauna in Their Natural State (1936) arts. 2, 4, 7-8.

116. GUHA (2000) pp. 46-47.

117. In this respect see BODANSKY et al. (2008) pp. 8-10.

118. REID (2015) p. 3.

119. Declaration of the United Nations Conference on the Human Environment (1972) principle 1. 120. SHELTON (1991) p. 112. See also UNITED NATIONS ECONOMIC AND SOCIAL COUNCIL (1994) para 31. 
Afterwards, the Rio Declaration on Environment and Development (Rio Declaration) separated itself from a human rights scope, maintaining that '[h] uman beings are at the centre of concerns for sustainable development. They are entitled to a healthy and productive life in harmony with nature. ${ }^{121}$ Despite the inaccurate linkage with human rights, the Rio Declaration acknowledged the importance that IP have regarding the environment 'because of their knowledge and traditional practices.' ${ }^{122}$ Additionally, Agenda 21 has depicted the importance of IP and their close relationship with the global environment ${ }^{123}$.

Even though Rio Declaration's distancing with HHRR, it let IEL move 'well beyond its original focus on interstate problems, while placing humans 'at the centre of concerns for sustainable development." ${ }^{124}$ Therefore, the linkage between IEL and HHRR can be shortened in two aspects: 'environmental protection may be cast as a means to the end of fulfilling human rights standards. [...] [And] the legal protection of human rights is an effective means to achieving the ends of conservation and environmental protection.' ${ }^{125}$ This affirmation describes the need for a supportive approach between both areas; they should no longer be separated fields of international law; thus, environmental rights emerged.

Finally, it is also noteworthy that, according to the IACrtHR, there is undeniable linkage between the protection of the environment and the realization of other human rights ${ }^{126}$; as environmental degradation and climate change directly affect the enjoyment of human rights.

\subsection{Environmental Rights}

HHRR and the environment have been mainly discussed by international and environmental academics; ; ${ }^{127}$ as well, it is notable the increasing number of cases that have been brought to international justice, implying the need to argue how both areas are intertwined. Hence, the definition to be considered in the current investigation is that environmental rights are those rights that are included in international environmental instruments that have a direct link with human rights and vice versa.

121. Rio Declaration on Environment and Development (1992) principle 1.

122. Op. cit., principle 22.

123. UNITED NATIONS (1992) chapter 26.

124. BIRNIE et al. (2009) p. 38.

125. ANDERSON (1996) p. 3; SHELTON (1991) pp. 112-113.

126. Advisory Opinion on Environment and Human Right OC-23/17, Inter-American Court of Human Rights Series A No 23 (15 November 2017), para 47.

127. BOYLE (2012) pp. 613-642; ANTON and SHELTON (2011); BOYLE (2008) pp. 471-511; BOYLE and ANDERSON (1996). 
The Rio Declaration recognised the procedural rights of access to information in environmental matters, participatory rights, and access to justice. ${ }^{128}$ Similarly, the Convention on Access to Information, Public Participation in Decision-Making and Access to Justice in Environmental Matters (Aarhus Convention) encompasses the same procedural rights; ${ }^{129}$ although it is a regional treaty, ${ }^{130}$ it possesses a global importance as it has been discussed at the Rio+2o UN Conference on Sustainable Development. ${ }^{131}$ As well, it has been considered as the "most ambitious venture in the field of environmental democracy under the auspices of the United Nations.' ${ }^{\prime 32}$

In this respect, fifteen countries from Latin America and the Caribbean signed the Regional Agreement on Access to Information, Public Participation and Justice in Environmental Matters in Latin America and the Caribbean (Escazu Agreement). ${ }^{133}$ This Agreement's objective is "to guarantee the full and effective implementation in Latin America and the Caribbean of the rights of access to environmental information, public participation in the decision-making process and access to justice in environmental matters." ${ }^{134}$ Yet, this instrument is still open for parties' ratification ${ }^{135}$.

128. Rio Declaration on Environment and Development (1992) principle 10.

129. Convention on Access to Information, Public Participation in Decision-Making and Access to Justice in Environmental Matters (2001) arts. 4-9.

130. UNITED NATIONS (2017) https://treaties.un.org/Pages/ViewDetails.aspx?src=IND\&mtdsg no=XXVII-13\&chapter=27\&clang=_en accessed 26 March 2018.

131. UNITED NATIONS ECONOMIC COMMISSION FOR EUROPE (2014) p. 3.

132. Ibid.

133. UNITED NATIONS ECONOMIC COMMISSION FOR LATIN AMERICA AND THE CARIBBEAN (2018) www.cepal.org/en/escazuagreement accessed 03 November 2018.

134. UNITED NATIONS ECONOMIC COMMISSION FOR LATIN AMERICA AND THE CARIBBEAN (2018) https://repositorio.cepal.org/bitstream/handle/11362/43583/1/S1800428_en.pdf accessed 03 November 2018.

135. UNITED NATIONS ECONOMIC COMMISSION FOR LATIN AMERICA AND THE CARIBBEAN (2018) www.cepal.org/en/escazuagreement accessed 03 November 2018. 
Regarding IP, mainly, two environmental treaties cover their rights: the CBD; which has a universal acceptation, ${ }^{136}$ and the Nagoya Protocol. ${ }^{137}$ The CBD forum has been one of the primary instances where IP can effectively participate; ${ }^{138}$ it calls on parties to respect, preserve and maintain IP's knowledge, innovations and practices applicable to a sustainable use of biological diversity, stating further the need to adequately share the benefits arising from their utilisation. ${ }^{139}$ For the purpose of establishing the scope and implementing this provision, the CBD COP has issued various decisions to develop it $^{140}$.

The Nagoya Protocol establishes the need of sharing with IP the benefits that may arise from the utilisation of genetic resources within their territories, in a fair and equitable way according to reached agreements. ${ }^{141}$ Furthermore, it compels States to obtain the prior and informed consent from IP, through their participation and reaching understandings, to use the traditional knowledge associated with genetic resources held by them; ${ }^{142}$ it also forbids States to restrict IP's customary practices and trading genetic resources among IP communities. ${ }^{143}$ However, neither the CBD ${ }^{144}$ nor the Nagoya Protocol ${ }^{145}$ will be discussed deeply in this work since it will divert the principal topic.

136. Convention on Biological Diversity 'List of Parties' (2017) www.cbd.int/information/ parties. shtml accessed 26 March 2018.

137. Nagoya Protocol on Access to Genetic Resources and the Fair and Equitable Sharing of Benefits Arising from Their Utilization to the Convention on Biological Diversity (2014).

138. MORGERA and TSIOUMANI (2011) p. 17.

139. Convention on Biological Diversity (1993) art. 8(j).

140. See Decision Adopted by the Conference of the Parties to the Convention on Biological Diversity at its Seventh Meeting (2004) section F; see also Decision Adopted by the Conference of the Parties to the Convention on Biological Diversity at its Twelfth Meeting (2014).

141. Nagoya Protocol on Access to Genetic Resources and the Fair and Equitable Sharing of Benefits Arising from Their Utilization to the Convention on Biological Diversity (2014) art. 5(2).

142. Op. cit., art. 7.

143. Op. cit., art. 12.

144. For a broader analysis see BIRNIE et al. (2009) chapter 11; MORGERA and TSIOUMANI (2011); BARSH (2008); RICHARDSON (2001) pp. 1-12.

145. For a broader analysis see MORGERA et al (2013a); MORGERA et al (2013b); VERMEYLEN (2013) p. 185-201. 
Various HHRR instruments refer directly to the right to a healthy environment, for instance: the African Convention on Human and Peoples' Rights, ${ }^{146}$ the Additional Protocol to the American Convention on Human Rights in the Area of Economic, Social and Cultural Rights, ${ }^{147}$ the UNDRIP ${ }^{148}$ and the ADRIP. ${ }^{149}$ All of them have recognised the right to a healthy environment, as some of the UN international declarations. ${ }^{150}$ In the same vein, the UN addressed this issue through the work of the Special Rapporteur Fatma Ksentini, who included in her report that '[a] ll persons have the right to a secure, healthy and ecologically sound environment [which is] universal, interdependent and indivisible. ${ }^{151}$

In this respect, in the Ogoniland case, the African Commission expressed and defined the scope of the right to a satisfactory or healthy environment. It maintained that this right is part of State's obligations and it 'requires the state to take reasonable and other measures to prevent pollution and ecological degradation, to promote conservation, and to secure an ecologically sustainable development and use of natural resources.' ${ }^{152}$

Moreover, the Office of the High Commissioner on Human Rights (OHCHR) has stated that despite the lack of an express recognition of the 'right to a safe and healthy environment, the United Nations human rights treaty bodies all recognize the intrinsic link between the environment and the realization of a range of human rights, such as the right to life, to health, to food, to water, and to housing.' ${ }^{153}$ Thus, it conceived the existence of the right to a clean environment. ${ }^{154}$

146. African Charter on Human and Peoples' Rights (1986) art. 24.

147. Additional Protocol to the American Convention on Human Rights in the Area of Economic, Social and Cultural Rights (1999) art. 11.

148. United Nations Declaration on the Rights of Indigenous Peoples (2007) art. 29.

149. American Declaration on the Rights of Indigenous Peoples (2016) art. 19.

150. UNITED NATIONS GENERAL ASSEMBLY (1990a) principle 23; United Nations General Assembly (1990b).

151. UNITED NATIONS ECONOMIC AND SOCIAL COUNCIL (1994) annex 1, principle 1.

152. Social and Economic Rights Action Center (SERAC) and Center for Economic and Social Rights (CESR) v Nigeria, African Commission on Human and Peoples' Rights, Communication 155/96 (2002) para. 52.

153. OFFICE OF THE UNITED NATIONS HUMAN RIGTHS COUNCIL (2009) para. 18.

154. OFFICE OF THE UNITED NATIONS HIGH COMMISSIONER FOR HUMAN RIGHTS (2011) para. 12. 
In this sense, international Human Rights Courts have tackled environmental related problems through the application of existing human rights, since, as stated, most of the relevant human rights' treaties do not encompass specific provisions on the right to a healthy environment; which has been identified as the "greening" of human rights ${ }^{155}$.

In this respect, the European Court of Human Rights (ECHR) has awarded a variety of cases that fall into the greening of human rights scope. It used arguments that were supported in the application of substantive human rights in an environmental context. For instance, in the cases of López Ostra, Guerra, Fadeyeva, Taskin, and Tatar, the Court addressed the complaint's environmental issues through the right to health; ${ }^{156}$ in Budayeva the Court made use of the right to life; ${ }^{157}$ and in Önerydildiz the ECHR referred to the right to property. ${ }^{158}$

On the other hand, the IACrtHR has expressly recognised the existence of an undeniable linkage between the protection of the environment and the enjoyment of other human rights ${ }^{159}$. The Court has gone beyond the traditional way of looking at environmental rights. It has stated that the right to a healthy environment protects the components of the environment, such as forests, rivers, seas, and others, as legal interests in themselves, even in the absence of certainty or evidence about the risk to individual persons.

155. BOYLE (2012) p. 614, 268; see also BOYLE (2008) p. 141; MAZZUOLI and MOREIRA TEIXEIRA (2015) p. 21.

156. López Ostra v Spain, Merits and just satisfaction, App No 16798/90, A/303-C, (1995) 20 EHRR 277, 9th December 1994, European Court of Human Rights; Guerra and others v Italy, Admissibility, merits and just satisfaction, App № 14967/89, Case № 116/1996/735/932, (1998) 26 EHRR 357, 19th February 1998, European Court of Human Rights; Fadeyeva v Russian Federation, Merits and just satisfaction, App No 55723/00, (2007) 45 EHRR 10, 9th June 2005, European Court of Human Rights; Taşkin and others v Turkey, Merits and just satisfaction, App № 46117/99, (2006) 42 EHRR 50, 10th November 2004, European Court of Human Rights; Tătar and Tătar v Romania, Merits and just satisfaction, App No 67021/01, 27th January 2009, European Court of Human Rights.

157. Budayeva and others v Russian Federation, Merits and just satisfaction, App No 15339/02, (2014) 59 EHRR 2, 20th March 2008, European Court of Human Rights.

158. Öneryıldız v Turkey, Merits and just satisfaction, App No 48939/99, (2005) 41 EHRR 20, 30th November 2004, European Court of Human Rights.

159. Case of Kawas-Fernández v. Honduras, Merits, Reparations and Costs, Judgement, InterAmerican Court of Human Rights Series C No 196 (3 April 2009), para 148. 
Furthermore, the right to a healthy environment is about to protect the nature and the environment, not to protect a person or group of persons directly. Not only because of its connectivity with the utility for the human being nor because their degradation effects might affect other human rights, such as health, life or personal integrity, rather because of its importance to the rest of the living organisms with whom the planet is shared, which are also worthy of protection ${ }^{160}$.

This solely paragraph entails a great advance in the securement of environmental rights, since it separates the commonly human-centred notion within IEL to a more ecological-centred approach. The environment, in the view of the Court, should be protected and preserved for its own nature; this protection does not longer involve a specific requirement to be implemented. In other words, the impairment of the right to life, health, property or any other human right is not a precondition to the protection of the environment per se. However, the right to a clean environment still has the nature of being considered as a human right, an autonomous one, though ${ }^{161}$.

Finally, the IACrtHR concluded that, in opposition of the European jurisprudence, multiple human rights are vulnerable to environmental degradation; which will force States to fulfil their environmental obligations in order to protect these rights ${ }^{162}$.

The current segment described, briefly, the connection between IEL and HHRR in the international arena, and how it has been addressed by international institutions. However, the discussion was not centred in whether it is necessary or not the inclusion of the right to a clean environment should be widely accepted, since the extensive doctrinal and philosophic discussions will stray us from the current issue. ${ }^{163}$

\section{The Environment and IP}

International law as a 'state-centered system, strongly grounded in the Western world view; [...] [was] developed to facilitate colonial patterns [...] to the detriment of indigenous peoples;' ${ }^{164}$ it 'is rooted in jurisprudential strains originating in classical Western legal thought. ${ }^{\prime 65}$ The Eurocentric essence of human rights and the environment

160. Advisory Opinion on Environment and Human Right OC-23/17, Inter-American Court of Human Rights Series A No 23 (15 November 2017), para 62.

161. Op. cit., para 63.

162. Op. cit., paras 55, 59.

163. MERRILLS (2018); BOYLE (2012); BIRNIEET al (2009) p. 271-302; CULLET (2016); TAYLOR (1998) pp. 309-397; RODRIGUEZ-RIVERA (2001) pp. 1-45.

164. ANAYA (2004) p. 15.

165. Ibid. 
has displaced IP's beliefs and the traditional connection with the latter. ${ }^{166}$ Nevertheless, international law has been combining non-Western ideas from international actors with different perspectives to the classical thought. ${ }^{167}$ This investigation will not criticise the implementation of Western legal concepts in international law; rather, it will make use of the founded institutions and combine them with IP's worldview.

In this context, international law has developed mechanisms in favour of IP's human rights; ${ }^{168}$ it is evident that IP's 'have gained unprecedented momentum, intersecting with the global debate concerning human rights, [...] climate change, sustainable development and environmental protection. ${ }^{169}$ Consequently, IP's concerns started to be treated within a holistic approach; however, the debate will focus mainly on the interaction of IP's human rights and the environment.

\subsection{The Environment as Part of Cultural Integrity}

It is necessary to refer briefly to IP's right to enjoy their own culture as a group, ${ }^{170}$ since, in the context of the right to self-determination, ${ }^{171}$ IP's relationship with the environment has its basis in central cultural values of their worldview, ${ }^{172}$ and it 'contributes to social stability, and is essential to human well-being. ${ }^{173}$ It entails, thus, the way in which IP understand the environment. ${ }^{174}$

166. SHUTKIN (1991) pp. 484-485.

167. ANAYA (2004) p. 15.

168. Op. cit., p. 4.

169. INTERNATIONAL LABOUR OFFICE (1989) p. xii.

170. For an extensive discussion on the right to cultural integrity, see ANAYA (2004) pp. 131- 141; GILLESPIE (2014) pp. 88-94; ODELLO (2012) pp. 25-50.

171. See section 2.3 .

172. Convention Concerning Indigenous and Tribal Peoples in Independent Countries (ILO N ${ }^{\circ}$ 169) (1991), arts. 2(2)(b), 5(a); American Declaration on the Rights of Indigenous Peoples (2016) art. 13(3), 19(1).

173. FIRESTONE et al. (2005) p. 222.

174. UNITED NATIONS EDUCATIONAL, SCIENTIFIC AND CULTURAL ORGANIZATION (1982)http://webarchive.unesco.org/20170204034755/http://portal.unesco.org/culture/en/ files/12762/11295421661mexico_en.pdf/mexico_en.pdf accessed 26 March 2018. 
In this respect, the UN Committee on the Elimination of Racial Discrimination has called upon States to recognise IP's distinct culture and to preserve it; warranting the exercise of IP's cultural traditions and customs ${ }^{175}$. As well, the Permanent Court of International Justice expressed, in the Minority Schools in Albania advisory opinion, that the basis for the protection of minorities groups, including IP, ${ }^{176}$ is to protect the population that differs from the rest of society, while preserving their distinctive characteristics, and to satisfy their unique needs ${ }^{177}$.

Additionally, the ICCPR expresses that minorities, including IP, have the right to enjoy their own culture with its members. ${ }^{178}$ The UNDRIP further develops this statement, explaining that the diversity of cultures is part of the common heritage of humankind; ${ }^{179}$ that cultural development is part of IP's right to self-determination; ${ }^{180}$ and that IP should not be forced to adapt to a different culture. ${ }^{181}$ As well, ADRIP ${ }^{182}$ and ILO $169^{183}$ have analogue provisions related to IP's cultural rights, same as other international instruments. ${ }^{184}$ Therefore, cultural integrity demonstrates that IP's tra-

175. INTERNATIONAL HUMAN RIGHTS INTRUMENTS (1997) pp. 212-213.

176. ANAYA (2004) p. 133-134.

177. Minority Schools in Albania (Advisory Opinion) [1935] PCIJ Rep Series A/B No 64, p. 17.

178. International Covenant on Civil and Political Rights (1976) art. 27.

179. United Nations Declaration on the Rights of Indigenous Peoples (2007) preamble.

180. Op. cit., art. 3.

181. Op. cit., art. 8(1).

182. American Declaration on the Rights of Indigenous Peoples (2016) preamble, arts. 2, 3, 10, 13 19, 28-29.

183. Convention Concerning Indigenous and Tribal Peoples in Independent Countries (ILO N ${ }^{\circ}$ 169) (1991) arts. 2(2)(b), 5(a).

184. See Convention on International Trade in Endangered Species of Wild Fauna and Flora (1975) preamble; Convention on Wetlands of International Importance especially as Waterfowl Habitat (1975) preamble; Convention on the Conservation of Migratory Species of Wild Animals (1983) preamble; United Nations (1972) recommendation 95; Declaration on the Rights of Persons Belonging to National or Ethnic, Religious and Linguistic Minorities (1992), United Nations General Assembly (1992); United Nations Educational, Scientific and Cultural.

Organization (1966) http://unesdoc.unesco.org/images/0011/001140/114048e.pdf\#page=82 accessed 26 March 2018; United Nations Educational, Scientific and Cultural Organization (2001); United Nations Educational, Scientific and Cultural Organization (2005) http://unesdoc. unesco. org/images/0014/001429/142919e.pdf accessed 26 March 2018; World Conference on Human Rights (1993) para 20, 28-32. 
ditions, knowledge, and way of living should be respected and recognised by international actors. IP's interaction with the environment, thus, is not a solitary aspect, rather as part of their own culture.

Regarding IEL, cultural rights may arise some challenges, e.g., IP's traditional hunting or fishing, as both activities are restricted by some environmental treaties. ${ }^{185}$ For instance, the International Convention for the Regulation of Whaling establishes some prohibitions on the hunting of whales that are endangered species; ${ }^{186}$ however, the International Whaling Commission has set up some exemptions regarding aboriginal subsistence whaling, separating it from commercial whaling. ${ }^{187}$ A Sub-Committee was founded to direct 'the regulations and management of this kind of whaling; ${ }^{188}$ nevertheless, the exemption granted to IP should be according to the objective of ensuring that the 'risk[s] of extinction to individual stocks are not seriously increased by subsistence whaling.'189

This last topic will lead to a broader discussion that will stray us from the current work. ${ }^{190}$ However, it falls on the growing reflections about IP's rights and interests at the international level; it is remarkable how their cultural heritage has been protected, although the problems that the aboriginal subsistence whaling exemption has faced during its developing and practise. ${ }^{191}$ Cultural integrity plays a transversal role while dealing with IP's rights, as it is considered as a fundamental human right, entailing a collective nature, and that must be respected in a multicultural, pluralist and democratic society. ${ }^{192}$

185. See Convention for the Protection of Migratory Birds in the United States and Canada (United States of America - Canada) (1916) art. 2; Convention for the Protection of Migratory Birds and Birds in Danger of Extinction and Their Environment (United States of America - Japan) (1972) art.

3; Convention Concerning the Conservation of Migratory Birds and Their Environment (United States of America - Union of Soviet Socialist Republic) (1976) art. 2.

186. International Convention for the Regulation of Whaling (1948) Schedule.

187. Ibid, Schedule para 13.

188. INTERNATIONAL WHALING COMMISSION 'Aboriginal Subsistence Whaling Sub-committee' (2017) https://iwc.int/aboriginal-subsistence-whaling-sub-committee accessed 26 March 2018.

189. GILLESPIE (2014) p. 88.

190. For a broader discussion see GILLESPIE (2001b) pp. 77-139.

191. Op. cit., pp. 79-86.

192. Advisory Opinion on Environment and Human Right OC-23/17, Inter-American Court of Human Rights Series A No 23 (15 November 2017), para 113. 


\subsection{IP's Worldview and the Environment}

During the United Nations Conference on Environment and Development, IP founded a parallel meeting and agreed on their own instrument: the Kari-Oca Declaration and the Indigenous Peoples' Earth Charter ${ }^{193}$ (hereinafter Kari-Oca Declaration). However, it is not part of International Public Law since it has not been adopted, signed nor ratified by any State; ${ }^{194}$ however, its importance resides in the worldwide participation of $\mathrm{IP}^{195}$ and the inclusion of their requests about issues regarding the environment and human rights.

Additionally, one of the most quoted documents that explain the relationship between IP and the environment is the letter from the Chief Seattle to the United States President in 1855. Despite the controversy about its origins; this letter will be used in the current work, not as a historic document, but, because of the relevance that its content presents to the investigation. ${ }^{196}$

The content of this letter will be considered in the current work as a valuable document that attempts to explain IP's worldview regarding environmental issues. The arguments found in this message are a representation of IP in the whole American Continent. ${ }^{197}$

Part of the letter reads as follows: 'This we know, the Earth does not belong to man; man belongs to the Earth. This we know, all things are connected, like the blood which unites one family. Whatever befalls the Earth, befalls the sons of the Earth. Man did not weave the thread of life; he is merely a strand in it. Whatever he does to the web he does to himself.' ${ }^{\prime 198}$

193. PORTAL OF CULTURE OF LATIN AMERICA AND THE CARIBBEAN, 'Kari-Oca Declaration and Indigenous Peoples' Earth Charter' (2016) www.lacult.unesco.org/doccult/listado. php?uid_ext=\&getipr=\&lg=2 accessed 26 March 2018.

194. Vienna Convention on the Law of Treaties (1980) art. 2(1)(a).

195. PORTAL OF CULTURE OF LATIN AMERICA AND THE CARIBBEAN, 'Kari-Oca Declaration and Indigenous Peoples' Earth Charter' (2016) www.lacult.unesco.org/doccult/listado. php?uid_ext=\&getipr=\&lg=2 accessed 26 March 2018 introduction.

196. National Archives "Prologue Magazine" (2017) www.archives.gov/publications/ prologue/1985/spring/chief-seattle.html accessed 03 November 2018.

197. ACOSTA (2013) pp. 15-20.

198. UNITED NATIONS ECONOMIC AND SOCIAL COUNCIL (1994) para 74. 
The statement demonstrates the close relationship that IP have with the environment itself; it is not intended to divide the humanity from it; rather the text seeks to make a stronger connection between them. It can be inferred that its arguments are founded upon the idea that 'humanity exists because of the Earth, its ecosystems, and the species upon it not the other way around.' ${ }^{199}$

The letter entails at least three key points. First, the environment is not considered itself as property; human beings do not own the environment, rather it works the other way around: we are part of the natural environment. Second, both humans and environment are part of one sole system; they are not separated entities, they are intimately connected, differing from Western standards. Finally, the harm caused to a part of the environment will affect the whole system, and by so, it also injuries humankind; the damage that we could cause to it will fall into us as well. ${ }^{200}$

The first assumption regarding the property will be covered in the following section, through the IACrtHR's scope about IP and the land. ${ }^{201}$ In order to understand the second conjecture, it is necessary to delimit the approaches that have been taken towards the environment from both indigenous and Western thought; while the third statement will lead to discuss briefly sustainable development.

\subsubsection{Definition of Environment}

IP's ideas and concepts of the environment diverge from conventional definitions. For instance, the term Gaia is mainly used to refer Earth as a 'self-regulating organism, ${ }^{202}$ in the basis of a scientific approach, ${ }^{203}$ and has gained acceptation in the scientific field worldwide. Alternatively, from an indigenous perspective, there are different names to refer to the planet Earth: Pachamama, ${ }^{204}$ Aluna, ${ }^{205}$ Coatlicue, ${ }^{206}$ and Iyatiku, ${ }^{207}$ to

199. GILLESPIE (2014) p. 14.

200. See also PORTAL OF CULTURE OF LATIN AMERICA AND THE CARIBBEAN, 'Kari-Oca Declaration and Indigenous Peoples' Earth Charter' (2016) www.lacult.unesco.org/doccult/ listado. php?uid_ext=\&getipr=\&lg=2 accessed 26 March 2018 paras 56, 84 .

201. See section 5 .

202. Oxford Living Dictionaries, 'Gaia' (2018) https://en.oxforddictionaries.com/definition/gaia accessed 26 March 2018.

203. For a full explanation see Lovelock (1991) pp. 21-34; see also Lovelock (2006) pp. 15-38.

204. ZAFFARONI (2012) p. 113.

205. SAHTOURIS (2000) p. 325

206. COTTERELL (2003)www.oxfordreference.com/view/10.1093/acref/9780192177476.001.0001/ acref-9780192177476, accessed 26 March 2018.

207. Ibid. 
name a few. These terms were not created through scientific basis; rather they have been developed by the ancestral cultural knowledge of coexistence with nature. ${ }^{208}$ For a better understanding, the term Pachamama will be used to encompass the various ways of referencing to mother Earth. ${ }^{209}$ The term "environment" is a Western construction; ${ }^{210}$ while Pachamama includes different conceptions, perceptions, and estimations of the nature itself. ${ }^{211}$

The Pachamama is a protective deity; ${ }^{212}$ she is the nature ${ }^{213}$ she is the cosmos and the time. ${ }^{214}$ According to the traditions, she gave us everything, but while staying inside her, she will also demand reciprocity, which 'becomes evident in all the ritual expressions of her cult; ${ }^{215}$ this argument leads to the inference that Pachamama is alive and sacred. It is also believed that all the things are interrelated, 'from a rock to human beings. ${ }^{\prime 216}$ Pachamama is also vulnerable, and if nobody looks after her, diseases might appear. ${ }^{217}$

208. ZAFFARONI (2012) p. 113.

209. PORTAL OF CULTURE OF LATIN AMERICA AND THE CARIBBEAN, 'Kari-Oca Declaration and Indigenous Peoples' Earth Charter' (2016) www.lacult.unesco.org/doccult/listado. php?uid_ext=\&getipr=\&lg=2 accessed 26 March 2018, preamble, paras 31-32.

210. GUDYNAS (2010) p. 52.

211. Ibid.

212. ZAFFARONI (2012) p. 117.

213. Op. cit., p. 118.

214. Op. cit., p. 119.

215. Op. cit., pp. 117-118.

216. SAHTOURIS (2000) p. 328. See also PORTAL OF CULTURE OF LATIN AMERICA AND THE CARIBBEAN, 'Kari-Oca Declaration and Indigenous Peoples' Earth Charter' (2016) www.lacult. unesco.org/doccult/listado.php?uid_ext=\&getipr=\&lg=2 accessed 26 March 2018 para 16-17. 217. ZAFFARONI (2012) p. 118. 
The Pachamama has let IP live, seed and hunt; she taught them how to enjoy the nature, but in an essential and adequate manner. ${ }^{218}$ Hence, one of the key points of IP's approach to the environment is that humans are part of it without owning it: living and non-living species interact and flow through the cosmic living space; which is moved by an energy that flows into the mutual cooperation among all the members of the cosmic wholeness. ${ }^{219}$

From a Western perspective, defining the environment has posed some complications. ${ }^{220}$ Besides, any international instrument has attempted to draw a definition of environment. ${ }^{221}$ Regarding international law, the ICJ has recognised that 'the environment is under daily threat [...] [and that it] is not an abstraction but represents the living space, the quality of life and the very health of human beings, including generations unborn. ${ }^{222}$ The Court did not define the term environment, but it maintains that its protection is a fundamental issue in international law.

The Stockholm Declaration referred to this topic through an anthropocentric scope, stating that the environment is 'essential to [mankind] well-being and to the enjoyment of basic human rights.'223 The Rio Declaration proclaimed that human beings 'are entitled to a healthy and productive life in harmony with nature, ${ }^{224}$ without defining the environment. This term is used in various treaties that deal with the harm to flora, fauna, air, aesthetics, marine environment, etc. ${ }^{225}$ Anthropocentrism has been displaced during the last years of IEL's evolution; which has detached from this perspective to rather aim to protect the environment itself..$^{226}$

\section{Ibid.}

219. Op. cit., p. 119.

220. BIRNIE et al. (2009) p. 5.

221. Op. cit., pp. 4-5.

222. Legality of the Threat or Use of Nuclear Weapons (Advisory Opinion) [1996] ICJ Rep, p. 226, para 29.

223. Declaration of the United Nations Conference on the Human Environment (1972) preamble, para. 1.

224. Rio Declaration on Environment and Development (1992) principle 1.

225. Convention on Biological Diversity (1993); Convention on International Trade in Endangered Species of Wild Fauna and Flora (1975); United Nations Convention on the Law of the Sea (1994); Convention on the Conservation of Antarctic Marine Living Resources (1982); Protocol on Environmental Protection to the Antarctic Treaty (1998); United Nations Framework Convention on Climate Change (1994); Montreal Protocol on Substances that Deplete the Ozone Layer (1989).

226. BIRNIE et al. (2009) pp. 7-8; BOYLE (1996); REDWELL (1996). 
Harmony is the basis of indigenous' relationship with the environment; and, remarkably, the World Charter for Nature has gone further in international law, asserting that ' $[\mathrm{m}]$ ankind is a part of nature and life depends on the uninterrupted functioning of natural systems. ${ }^{\prime 27}$ This argument is the first notable connection that IEL has with IP's conceptions about the environment, by considering human beings as part of the nature and stating that life depends on the cycle of natural systems, recognising the intrinsic value of each organism 'regardless of its worth to man.'228

\subsubsection{Sustainable Development and IP}

The Pachamama might get offended when their sons are mistreated. ${ }^{229}$ However, she does not obstruct hunting, fishing, or woodcutting, only when these activities do not lead to resource devastation. ${ }^{230}$ Some IP groups still rely on hunting and gathering to fulfil their needs: for instance, whaling has been a primordial way of surviving for some of them. ${ }^{231}$

IP's worldview does not intend to ban industrial activities, in fact, it 'suggests that the wisdom and knowledge of indigenous peoples must provide the context in which [the] make, use and dispose of industrial goods [should be done] if we are to survive. ${ }^{232}$ Then, the intent of IP is to use their resources without causing significant harm to the environment while pursuing their needs; which is well supported by sustainable development; ${ }^{233}$ both argumentative threads do not clash themselves, they are supportive.

227. UNITED NATIONS GENERAL ASSEMBLY (1990a) preamble.

228. Ibid.

229. ZAFFARONI (2012) p. 118.

230. Ibid. See also PORTAL OF CULTURE OF LATIN AMERICA AND THE CARIBBEAN, 'KariOca Declaration and Indigenous Peoples' Earth Charter' (2016) www.lacult.unesco.org/doccult/ listado. php?uid_ext=\&getipr=\&lg=2 accessed 26 March 2018 para. 66-67.

231. See section 4.1.

232. SAHTOURIS (2000) p. 326. See also ZAFFARONI (2012) p. 118.

233. RICHARDSON and CRAIG (2006) p. 195-203. See also MILLER (2007), pp. 8-48. 
Sustainable development ${ }^{234}$ has been widely recognised by international law. ${ }^{235}$ The Rio Declaration has stated that human beings should live in harmony with the environment; ${ }^{236}$ which does not mean a prohibition to make use of natural resources; in fact, it refers to the requirement of carrying activities but bearing in mind environmental protection. ${ }^{237}$ This approach was sustained by the ICJ in the Gabcikovo-Nagymaros case, where the Court stated that sustainable development is fulfilled when economic development and environmental protection are met; ${ }^{238}$ furthermore, in the Pulp Mills case, the ICJ held the need of an optimum and rational utilisation of resources, by balancing economic activities with the obligation of protecting the environment. ${ }^{239}$ Additionally, the Appellate Body of the World Trade Organization, in the case, has also dealt with the applicability of sustainable development. ${ }^{240}$

Consequently, it is notable that the concept, or principle, ${ }^{241}$ of sustainable development, which was already issued by antique cultures, ${ }^{242}$ is a common concern of both Western and non-Western approaches; the exploitation of natural resources is not banned at all in either of both streams, the only requirement is to undertake any activity by considering the protection of the environment.

234. For an extensive discussion see BIRNIE et al. (2009) pp. 53-58, 115-127, 190-205; BEYERLIN and MARAUHN (2011) pp. 73-84; MAGRAW and HAWKE (2008); Sands (2008); BOYLE and FREESTONE (1999); GILLESPIE (2001a); HEY (2003) pp. 3-53.

235. United Nations Framework Convention on Climate Change (1994) arts. 2, 3(4); Convention on Biological Diversity (1993) art. 1; Convention on Access to Information, Public Participation in Decision-Making and Access to Justice in Environmental Matters (2001) preamble; Paris Agreement (2016) preamble, arts. 2, 4-8, 10; Convention on Environmental Impact Assessment in a Transboundary Context (1997) preamble.

236. Rio Declaration on Environment and Development (1992) principle 1.

237. Op. cit., principles 3, 4, 6-7.

238. Gabcikovo-Nagymaros Project (Hungary v Slovakia) (Judgment) [1997] ICJ Rep, p. 7 para 140. 239. Pulp Mills on the River Uruguay (Argentina v. Uruguay) (Judgment) [2010] ICJ Rep, p. 14 paras 170-177, 183-187.

240. See United States - Import Prohibition of Certain Shrimp and Shrimp Products-Report of the Appellate Body (12 October 1998) WT/DS58/AB/R, paras 128-134, 152-154.

241. Gabcikovo-Nagymaros Project (Hungary v Slovakia) (Judgment) [1997] ICJ Rep, p. 7, Separate Opinion of Vice-President Weeramantry, p. 91 www.icj-cij.org/files/case-related/92/09219970925-JUD-01-03-EN.pdf accessed 26 March 2018. p. 88.

242. RICHARDSON and CRAIG (2006) p. 195. 
Environmental problems can be tackled through the employment of IP's environmental points. Their tradition protects both living and non-living organisms, disregarding their mass, or the place where they live, and, it does not displace the inherent dignity of the human being; in fact, it may restore us from the path of domination and accumulation. ${ }^{243}$ Thus, a question might arise out of the debate: What if we go deeper and try to merge IP's environmental worldview into a Western based national and international legal system?

These indigenous' conceptions are the basis of a novel public policy: "sumak kawsay," which is the life process that comes from the community mould of peoples who live in harmony with nature. It is a qualitative step that overtakes the traditional concept of development. ${ }^{244}$ It can hardly be compared to the Western idea of welfare. ${ }^{245}$ Both the Pachamama and sumak kawsay have led two American countries to go even further in the development of environmental law: Ecuador and Bolivia. Both countries' Constitutions, founded by IP's worldview, have considered these principles as the foundation of nature's rights; ${ }^{246}$ which was extended even to various countries globally. ${ }^{247}$

These perceptions have led to discuss environmentalism in international law; ${ }^{248}$ two points of view have resulted from this argument. First, the classical environmentalism represented by the statement that "trees have rights;" by supporting that, "nature itself is entitled to protection because it is intrinsically valuable, independently of whatever utility nature has for humanity. ${ }^{249}$ This argument is an elitist point of

243. ZAFFARONI (2012) p. 127.

244. ACOSTA (2013) p. 15. See also DE SOUSA SANTOS (2010) pp. 45-51; 60-61; 94-98.

245. ACOSTA (2013) p. 16.

246. Constitution of the Republic of Ecuador (2008) preamble, arts. 71-74; Political Constitution of Bolivia (2009) arts. 33-34.

247. See Corte Constitucional [C.C.] [Constitutional Court], noviembre 10, 2016, Sentencia T-622/16 (Colom.). (corteconstitucional.gov.co 2017) www.corteconstitucional.gov.co/ relatoria/2016/t-622-16.htm accessed 26 March 2018; Corte Suprema de Justicia [CSJ] [Supreme Court] Sal. Civ. julio 26, 2017, L.A. Tolosa, Radicación 17001-22-13-000-2017-00468-02 (Colom.); see also New Zealand Legislation 'Te Awa Tupua (Whanganui River Claims Settlement) Act 2017' (legislation.govt.nz, 2017) www.legislation.govt.nz/act/public/2017/0007/latest/whole.html accessed accessed 26 March 2018; see also The Guardian 'Ganges and Yamuna rivers granted same legal rights as human beings' (theguardian.com, 2017) www.theguardian.com/world/2017/mar/21/ ganges-and-yamuna-rivers-granted-same-legal-rights-as-human-beings accessed 26 March 2018.

248. For an extensive discussion on this matter see REDWELL (1996); GUDYNAs (2010); AcostA (2013); TAYLOR (1998); CULLINAN (2002); BEDÓN (2016) pp. 133-148; SECRETARÍA NACIONAL DE PLANIFICACIÓN Y DESARROLLO (2010); CRUZ (2014) pp. 95-116.

249. $\operatorname{ANAYA(1999)~pp.~1-2.~}$ 
view, only held by those who have the time to talk about the intrinsic value of the environment. ${ }^{250}$ Second, the proposal to provide value to the nature in accordance to the interests of humanity ${ }^{251}$ attempts to establish a connection between 'the welfare of humanity, the dignity of human beings, and the environment. ${ }^{252}$

On the other hand, Zaffaroni has argued that nature's rights play a major role in the evolution of universal law. ${ }^{253}$ In this sense, he denies the possible affirmation that the inclusion of these rights into a legal system obeys only to a folkloric expression of a country. ${ }^{254}$ Furthermore, he compares this novel rights' inclusion with what happened in the last century in the field of Human Rights, when the international community shifted their paradigm by recognising that every human being is a person. ${ }^{255}$

Getting deeper in this discussion will diverge us from our current topic. However, we can conclude that IP's customs, although not based on a scientific basis, will, at some point, converge with the Western thinking: Gaia and Pachamama is the encounter 'of a scientific culture that alarms itself and a traditional culture that already knew the peril, even how to prevent it and heal it, ${ }^{{ }^{256}}$ respectively. There is a lot to learn from IP; it is just about going through a paradigm shift. ${ }^{257}$

\section{The IACrtHR and IP's Worldview Connection}

IP's issues have been gaining importance gradually in international law. ${ }^{25}$ However, this advancement was not conceived without a struggle. The IACrtHR has been dealing with IP's claims regarding their environmental rights; ${ }^{259}$ it played a vital role in the development of their claims, and it possesses the most relevant case-law concerning this issue. For this section, it is inevitable to keep in mind that environmental rights violations will affect more deeply to IP, as they are considered by international law as part of vulnerable groups. ${ }^{260}$

250. Ibid.

251. Ibid.

252. Ibid.

253. ZAFFARONI (2012) pp. 130-144.

254. Op. cit., p. 114.

255. Op. cit., p. 115.

256. Op. cit., p. 145.

257. CULLINAN (2002) pp. 49-50.

258. See section 2.

259. ANAYA and WILLIAMS (2001) p. 33-37; BARELLI (2010) pp. 962-963.

260. Advisory Opinion on Environment and Human Right OC-23/17, Inter-American Court of Human Rights Series A No 23 (15 November 2017), para 67. 
Furthermore, the Court has addressed that States, while dealing with IP's rights, shall take into account the differentiated impact that they might have from the rest of the population. ${ }^{261}$ The Advisory Opinion on Human Rights and the Environment had its basis in IP-related prior awards, in order to reach to the main arguments within in. ${ }^{262}$

\subsection{Collective Right to Property}

IP do not see their lands as an individual asset; the IACrtHR stated that 'there is a communitarian tradition regarding a communal form of collective property of the land; ${ }^{263}$ which focuses on the community as a group, instead of delimiting it to one of their members. Hence, the Court has made clear the existing difference between Western and IP's thoughts about land ownership; ${ }^{264}$ however, both notions of possession deserve the same protection. ${ }^{265}$

IP's conceptions do not discard the individual aspect of property; the Court sustained that the Inter-American system of Human Rights 'protects the right to property in a sense which includes, among others, the rights of members of the indigenous communities within the framework of communal property. ${ }^{266}$ Likewise, the Court determined that the collective right to property is essential for IP's survival and their cultural and developmental objectives; ${ }^{267}$ in other words, the collective aspect of the right to land property has its basis in IP's right to self-determination.

The collective aspect of land rights is endorsed by international law. ${ }^{268}$ The IA-

261. Op. cit., para 68.

262. Op. cit., para 48.

263. Case of the Mayagna (Sumo) Awas Tingni Community v. Nicaragua, Merits, Reparations and Costs, Judgement, Inter-American Court of Human Rights Series C No 79 (31 January 2001) para. 149.

264. Case of the Kichwa Indigenous People of Sarayaku v. Ecuador, Merits and Reparations, Judgment Inter-American Court of Human Rights Series C No 245 (27 June 2012) para. 145.

265. Ibid.

266. Case of the Mayagna (Sumo) Awas Tingni Community v. Nicaragua, Merits, Reparations and Costs, Judgement, Inter-American Court of Human Rights Series C No 79 (31 January 2001), para. 148.

267. Case of the Yakye Axa Indigenous Community v. Paraguay, Merits, Reparations and Costs, Judgement, Inter-American Court of Human Rights Series C No 125 (17 June 2005) para. 146.

268. Convention Concerning Indigenous and Tribal Peoples in Independent Countries (ILO No 169) (1991) art. 13(1); UNDRIP preamble, arts. 1, 7(2); American Declaration on the Rights of Indigenous Peoples (2016) arts. 1, 6, 13, 16, 18-19, 26-28, 33. 
CrtHR was the first international institution in ruling IP's communal property, ${ }^{269}$ by guaranteeing it to the community as a whole. ${ }^{270}$ In the same vein, the Court, by its Advisory Opinion on Human Rights and the Environment, determined that the lack of IP's access to their lands and resources might expose them to precarious or subhuman life conditions. ${ }^{271}$

Furthermore, ADRIP has, also, recognised collective rights by stating that they are 'indispensable for [IP's] existence, well-being, and integral development as peoples. ${ }^{\prime 272}$

\subsection{Lands}

Many international instruments recognise IP's relationship with lands; ${ }^{273}$ and it is conceived to be more ancient than Western ways of ownership. ${ }^{274}$ In fact, the IACrtHR has distanced itself from the traditional property conceptions, by maintaining that '[a]s a result of customary practices, possession of the land should suffice for indigenous communities lacking real title to property of the land to obtain official recognition of that property, and for consequent registration.'.275 IP's property regimes should not need a prior acceptance from States to exist. ${ }^{276}$

269. WILSON and PERLIN (2003) p. 685.

270. See also Maya Indigenous Communities of the Toledo District (Belize), Merits, Inter- American Commission on Human Rights, Report No 40/04, case 12.053 (12 October 2004) para 112-113.

271. Advisory Opinion on Environment and Human Right OC-23/17, Inter-American Court of Human Rights Series A No 23 (15 November 2017), para 48.

272. American Declaration on the Rights of Indigenous Peoples (2016) art. 6.

273. See Convention Concerning Indigenous and Tribal Peoples in Independent Countries (ILO № 169) (1991) arts 13-19; United Nations Declaration on the Rights of Indigenous Peoples (2007) preamble, arts. 8(2)(b), 10, 26-27; American Declaration on the Rights of Indigenous Peoples (2016) preamble, arts. $6,19,25,26(2)$.

274. PITTY (2001) p. 50. See also Maya Indigenous Communities of the Toledo District (Belize), Merits, Inter-American Commission on Human Rights, Report No 40/04, case 12.053 (12 October 2004) para 127.

275. Case of the Mayagna (Sumo) Awas Tingni Community v. Nicaragua, Merits, Reparations and Costs, Judgement, Inter-American Court of Human Rights Series C No 79 (31 January 2001) para 151. In this respect, see also Case of the Sawhoyamaxa Indigenous Community v. Paraguay, Merits, Reparations and Costs, Judgment Inter-American Court of Human Rights Series C No 146 (29 March 2006) para 128.

276. ANAYA and WILLIAMS (2001) p. 46. 
The Court recognised the importance of IP's connection with their lands since it is the basis for their economic, social, and cultural existence; ${ }^{277}$ as for their spiritual life and integrity. ${ }^{278}$ This right has, according to the Court, two unique qualities: material and spiritual. The former is linked with productive and economic aspects of IP's life, such as the access to natural resources, ${ }^{279}$ while the latter is based on their religiosity and worldview. ${ }^{280}$

In the same sense, the Court, through its Advisory Opinion on Human Rights and the Environment, has determined that States shall adopt positive measures in order to ensure IP's access to a decent existence and to their life projects, which entails the protection of their close linkage with their lands. ${ }^{281}$

However, the IACrtHR established four parameters to be considered to enforce this right. First, a temporal restriction, as long as the relationship still exists between IP and their lands. ${ }^{282}$ Second, in conflicts between the State or private actors and IP, the latter's interests will not always prevail. ${ }^{283}$ Third, IP should be able to express

277. Case of the Saramaka People v. Suriname, Merits, Reparations and Costs, Judgement, InterAmerican Court of Human Rights Series C No 172 (28 November 2007) para 91; see also Case of the Xákmok Kásek Indigenous Community v. Paraguay, Merits, Reparations and Costs, Judgement, Inter-American Court of Human Rights Series C No 214 (24 August 2010) para 85.

278. Case of the Mayagna (Sumo) Awas Tingni Community v. Nicaragua, Merits, Reparations and Costs, Judgement, Inter-American Court of Human Rights Series C No 79 (31 January 2001) para 149. 279. Case of the Yakye Axa Indigenous Community v. Paraguay, Merits, Reparations and Costs, Judgement, Inter-American Court of Human Rights Series C No 125 (17 June 2005) para 164.

280. Ibid, para 135; see also Case of the Sawhoyamaxa Indigenous Community v. Paraguay, Merits, Reparations and Costs, Judgment Inter-American Court of Human Rights Series C No 146 (29 March 2006) para 118; Case of the Saramaka People v. Suriname, Merits, Reparations and Costs, Judgement, Inter-American Court of Human Rights Series C No 172 (28 November 2007) para 95; Case of the Kichwa Indigenous People of Sarayaku v. Ecuador, Merits and Reparations, Judgment Inter-American Court of Human Rights Series C No 245 (27 June 2012) para 155. See also American Declaration on the Rights of Indigenous Peoples (2016) art. 25(1).

281. Advisory Opinion on Environment and Human Right OC-23/17, Inter-American Court of Human Rights Series A No 23 (15 November 2017), para 48.

282. Case of the Sawhoyamaxa Indigenous Community v. Paraguay, Merits, Reparations and Costs, Judgment Inter-American Court of Human Rights Series C No 146 (29 March 2006) para 131.

283. Case of the Yakye Axa Indigenous Community v. Paraguay, Merits, Reparations and Costs, Judgement, Inter-American Court of Human Rights Series C No 125 (17 June 2005) para 149. 
this relationship, according to their specific conditions, ${ }^{284}$ through the evidence of traditional use, settlements, cultivation, hunting, etc. ${ }^{285}$ Finally, the relationship must be possible, ${ }^{286}$ which means that they should not be prevented from carrying those activities. $^{287}$

On the other hand, IP's conceptions describe the ancestral connection that they maintain with their lands. ${ }^{28}$ The Kari-Oca Declaration affirms that the Pachamama placed them in their lands, they belong to the land and they should not be separated from it, ${ }^{289}$ their territories are 'living totalities in permanent vital relation between human beings and nature ${ }^{290}$ (spiritual feature); and, land is crucial for the development of their culture ${ }^{291}$ (material feature). Furthermore, the Declaration confronts the Western concept of ownership, since it has caused severe damage to their people; ${ }^{292}$ especially, it requests the elimination of the concept of terra nullus from international law. ${ }^{293}$

284. Case of the Kichwa Indigenous People of Sarayaku v. Ecuador, Merits and Reparations, Judgment Inter-American Court of Human Rights Series C No 245 (27 June 2012) para 148.

285. Ibid, see also Case of the Yakye Axa Indigenous Community v. Paraguay, Merits, Reparations and Costs, Judgement, Inter-American Court of Human Rights Series C No 125 (17 June 2005) para. 154; Case of the Xákmok Kásek Indigenous Community v. Paraguay, Merits, Reparations and Costs, Judgement, Inter-American Court of Human Rights Series C No 214 (24 August 2010) para 113.

286. Case of the Kichwa Indigenous People of Sarayaku v. Ecuador, Merits and Reparations, Judgment Inter-American Court of Human Rights Series C No 245 (27 June 2012) para 148.

287. Ibid; see also Case of the Sawhoyamaxa Indigenous Community v. Paraguay, Merits, Reparations and Costs, Judgment Inter-American Court of Human Rights Series C No 146 (29 March 2006) para 132; Case of the Xákmok Kásek Indigenous Community v. Paraguay, Merits, Reparations and Costs, Judgement, Inter-American Court of Human Rights Series C No 214 (24. August 2010) para 113; Case of the Saramaka People v. Suriname, Merits, Reparations and Costs, Judgement, InterAmerican Court of Human Rights Series C No 172 (28 November 2007) para 143.

288. See section 4.2 .

289. PORTAL OF CULTURE OF LATIN AMERICA AND THE CARIBBEAN, 'Kari-Oca Declaration and Indigenous Peoples' Earth Charter' (2016) www.lacult.unesco.org/doccult/listado. php?uid_ext=\&getipr=\&lg=2 accessed 26 March 2018 para 31 .

290. Op. cit., para 32.

291. Ibid.

292. Op. cit., para 77.

293. Op. cit., paras 6, 36. 
Therefore, the linkage between IP and their lands was not built solely on the base of the spiritual connection; they also acknowledge the material value of their territories and the importance of this aspect for their survival and vitality. ${ }^{294}$ In various human rights forums, IP have affirmed that 'the spiritual and material foundations of their cultural identities are sustained by their unique relationships to their traditional territories. ${ }^{295}$ The Inter-American system has recognised IP's right to property ${ }^{296}$ as a fundamental condition for their survival; ${ }^{297}$ IP's beliefs, then, have contributed to the development of international law in this regard.

\subsection{Natural Resources}

International law instruments cover IP's ownership and use of natural resources. ${ }^{298}$ The IACrtHR has discussed this matter by upholding that the right to land would be 'meaningless [...] if that right were not connected to the natural resources that lie on and within the land, ${ }^{\prime 299}$ and to their protection. ${ }^{300}$ In this sense, the IACrtHR has defined natural resources as 'those material things which can be possessed [...]; [it] includes all movables and immovables, corporeal and incorporeal elements and any other intangible object capable of having value.'301

Moreover, the Court has maintained that IP own natural resources located in their territories for the same reasons that they have the right to own their ancestral lands. ${ }^{302}$

294. UNITED NATIONS COMMISSION ON HUMAN RIGHTS (2001) para 12.

295. WILLIAMS (1990) p. 689.

296. Maya Indigenous Communities of the Toledo District (Belize), Merits, Inter-American Commission on Human Rights, Report No 40/04, case 12.053 (12 October 2004) para 112-113. para 115. 297. Case of the Yakye Axa Indigenous Community v. Paraguay, Merits, Reparations and Costs, Judgement, Inter-American Court of Human Rights Series C No 125 (17 June 2005) para 147.

298. Convention Concerning Indigenous and Tribal Peoples in Independent Countries (ILO No 169) (1991) art. 15; United Nations Declaration on the Rights of Indigenous Peoples (2007) preamble, arts. 25-29, 32; American Declaration on the Rights of Indigenous Peoples (2016) preamble, arts. 6, 19, 25, 29.

299. Case of the Saramaka People v. Suriname, Merits, Reparations and Costs, Judgement, InterAmerican Court of Human Rights Series C No 172 (28 November 2007) para 122.

300. Case of the Kichwa Indigenous People of Sarayaku v. Ecuador, Merits and Reparations, Judgment Inter-American Court of Human Rights Series C No 245 (27 June 2012) para 146.

301. Case of the Mayagna (Sumo) Awas Tingni Community v. Nicaragua, Merits, Reparations and Costs, Judgement, Inter-American Court of Human Rights Series C No 79 (31 January 2001) para 144. 302. Case of the Saramaka People v. Suriname, Merits, Reparations and Costs, Judgement, InterAmerican Court of Human Rights Series C No 172 (28 November 2007) para 121. 
Resources will support their survival and will avoid their extinction. ${ }^{303}$ Hence, the basis of this right is that IP should continue with their traditional way of living, by respecting and protecting their traditions and beliefs; ${ }^{304}$ which entails the recognition of the existing linkage between the use of resources with IP's spiritual life ${ }^{305}$ and the respect of their traditional way of using them..$^{306}$

Additionally, the Court held that protection must be given to 'those natural resources traditionally used and necessary for the very survival, development and continuation of [IP's] way of life. ${ }^{307}$ It also covers those resources whose exploitation may cause damage to those that have been used in a traditional way by IP, since 'the extraction of one natural resource is most likely to affect the utilisation and enjoyment of other natural resources that are necessary for the survival of [IP] ${ }^{308}$

However, there are some limitations ${ }^{309}$ for the exercise of this right, since it should not entirely prevent States to grant concessions to exploit natural resources within indigenous' lands. ${ }^{310}$ The Court established some requirements to consider the lega-

\section{Ibid.}

304. Ibid; see also Case of the Kichwa Indigenous People of Sarayaku v. Ecuador, Merits and Reparations, Judgment Inter-American Court of Human Rights Series C No 245 (27 June 2012) para 146.

305. Case of the Yakye Axa Indigenous Community v. Paraguay, Merits, Reparations and Costs, Judgement, Inter-American Court of Human Rights Series C No 125 (17 June 2005) para 135, 137; see also Case of the Sawhoyamaxa Indigenous Community v. Paraguay, Merits, Reparations and Costs, Judgment Inter-American Court of Human Rights Series C No 146 (29 March 2006) para 118, 121; Case of the Xákmok Kásek Indigenous Community v. Paraguay, Merits, Reparations and Costs, Judgement, Inter-American Court of Human Rights Series C No 214 (24 August 2010) para 85; Case of the Kichwa Indigenous People of Sarayaku v. Ecuador, Merits and Reparations, Judgment InterAmerican Court of Human Rights Series C No 245 (27 June 2012) para 145.

306. Case of the Yakye Axa Indigenous Community v. Paraguay, Merits, Reparations and Costs, Judgement, Inter-American Court of Human Rights Series C No 125 (17 June 2005) para 140.

307. Case of the Saramaka People v. Suriname, Merits, Reparations and Costs, Judgement, InterAmerican Court of Human Rights Series C No 172 (28 November 2007) para 122.

308. Ibid, para 126.

309. Case of the Yakye Axa Indigenous Community v. Paraguay, Merits, Reparations and Costs, Judgement, Inter-American Court of Human Rights Series C No 125 (17 June 2005) para 144; see also Case of the Saramaka People v. Suriname, Merits, Reparations and Costs, Judgement, InterAmerican Court of Human Rights Series C No 172 (28 November 2007) para 127.

310. Case of the Saramaka People v. Suriname, Merits, Reparations and Costs, Judgement, InterAmerican Court of Human Rights Series C No 172 (28 November 2007) para 126. 
lity of these restrictions, ${ }^{311}$ mainly when expropriation is considered. In this context, States 'must assess, on a case by case basis, the restrictions that would result from recognizing one right over the other, ${ }^{\prime 32}$ by considering the importance of indigenous' relationship with land and resources. These right limitations led the Court to establish some safeguards, ${ }^{313}$ which will be discussed below. ${ }^{314}$

On the other hand, pursuant IP's worldview, natural resources should be managed in a sustainable way. ${ }^{315}$ The Kari-Oca Declaration aims to protect the environment, by not pursuing economic growth over all things; it intends to avoid activities that may cause serious harm to the environment. ${ }^{16}$ However, IP's beliefs do not stand against industrial activities; they only agreed to allow activities that do not suppose significant harm to themselves or the environment. The Declaration expressed that certain events must end to stop environmental degradation, as changing a part of the ecosystem will affect its wholeness. ${ }^{317}$

For these reasons, it can be ascertained that IP's worldview has influenced in the Court's decisions regarding land and natural resources. However, it is not clear yet the approach that the Court may have when a purely environmental claim is brought to the American Human Rights System, as there is not yet a request about the protection of the environment per se; which has been considered merely as a precondition to guarantee other human rights. ${ }^{318}$

311. Case of the Yakye Axa Indigenous Community v. Paraguay, Merits, Reparations and Costs, Judgement, Inter-American Court of Human Rights Series C No 125 (17 June 2005) art. 21(1).

312. Case of the Yakye Axa Indigenous Community v. Paraguay, Merits, Reparations and Costs, Judgement, Inter-American Court of Human Rights Series C No 125 (17 June 2005) para 146.

313. Case of the Saramaka People v. Suriname, Merits, Reparations and Costs, Judgement, InterAmerican Court of Human Rights Series C No 172 (28 November 2007) para 129. See also Advisory Opinion on Environment and Human Right OC-23/17, Inter-American Court of Human Rights Series A No 23 (15 November 2017), para 156.

314. See section 5.4 .

315. See section 4.2

316. PORTAL OF CULTURE OF LATIN AMERICA AND THE CARIBBEAN, 'Kari-Oca Declaration and Indigenous Peoples' Earth Charter' (2016) www.lacult.unesco.org/doccult/listado. php?uid_ext=\&getipr=\&lg=2 accessed 26 March 2018 paras 45-50, 54, 58.

317. Op. cit., para 56.

318. Inter-American Commission on Human Rights 'Report on the Situation of Human Rights in Ecuador' (24 April 1997) Doc. OEA/Ser.L/V/II.96 Doc. 10 rev. 1 www.cidh.org/countryrep/ecuador-eng/Chaper-8.htm accessed 26 March 2018. 


\subsection{Safeguards}

The IACrtHR has defined three requirements, that must be applied in any investment plan, to 'preserve, protect and guarantee the special relationship that [IP] have with their territory. ${ }^{\prime 19}$ First, States must ensure IP's effective participation in activities that may affect their lands' integrity; second, States must guarantee a benefit-sharing scheme resulted from these activities; and, third, States must ensure that a Social and Environmental Impact Assessment is carried out before granting any concession.

\subsubsection{Consultation and Participation}

Considered as the cornerstone of procedural rights; ${ }^{320}$ consulting IP will entitle them to participate effectively in decision-making processes. ${ }^{321}$ The right to public participation $^{322}$ has been considered in IEL ${ }^{323}$ and in IP international framework. ${ }^{324}$ In this respect, the IACrtHR has determined that States must make public the information that interests to IP and maintain a constant communicational channel. ${ }^{325}$ Furthermore, it established certain basic features as to achieve this right.

319. Case of the Saramaka People v. Suriname, Merits, Reparations and Costs, Judgement, InterAmerican Court of Human Rights Series C No 172 (28 November 2007) para 129.

320. Advisory Opinion on Environment and Human Right OC-23/17, Inter-American Court of Human Rights Series A № 23 (15 November 2017), para 226.

321. Inter-American Commission on Human Rights, 'Indigenous and Tribal Peoples' Rights over their Ancestral Lands and Natural Resources, Norms and Jurisprudence of the Inter-American Human Rights System' (30 December 2009) Doc. OEA/Ser.L/V/II, Doc. 56/09, paras 274-275, 277. See also Advisory Opinion on Environment and Human Right OC-23/17, Inter-American Court of Human Rights Series A No 23 (15 November 2017), para 228, 231-232.

322. For a complete reference on this matter see EBBESSON (2008).

323. Rio Declaration on Environment and Development (1992) principle 10; Convention on Access to Information, Public Participation in Decision-Making and Access to Justice in Environmental Matters (2001) preamble, arts. 1, 3, 6-8; United Nations General Assembly (1990a) principle 23; see also International Law Commission Report (2001).

324. Convention Concerning Indigenous and Tribal Peoples in Independent Countries (ILO No 169) (1991) arts. 6, 7(1), 15(2), 22, 27-28; United Nations Declaration on the Rights of Indigenous Peoples (2007) arts. 10-11, 17-19, 27-30, 32, 36, 38; American Declaration on the Rights of Indigenous Peoples (2016) arts. 6, 13-14, 18, 20-21, 23, 28(3), 29, 31, 33-34.

325. Case of the Saramaka People v. Suriname, Merits, Reparations and Costs, Judgement, InterAmerican Court of Human Rights Series C No 172 (28 November 2007) para 133. See also Advisory Opinion on Environment and Human Right OC-23/17, Inter-American Court of Human Rights Series A No 23 (15 November 2017), paras 213-225. 
First, consultations must be in good faith, which entails parties' mutual trust and the absence of external pressure. ${ }^{326}$ Second, consultations must be carried out beforehand the initiation of a project, so IP would be able to discuss its features and give a suitable response, ${ }^{327}$ and, thus, 'truly participate in and influence the decisionmaking process. ${ }^{\prime 28}$ Third, the State must put into consideration the benefits and the possible environmental and health risks that the plan might involve, so that IP may accept it willingly. ${ }^{329}$ Finally, States must take into account a culturally adequate process of consultation by considering IP's traditional process of decision-making. ${ }^{330}$

For this purpose, the Court enumerated the circumstances when States must consult IP; ${ }^{311}$ however, when the proposed plan would entail a large-scale project, it will be compulsory to obtain their free, prior and informed consent in accordance with their traditions. ${ }^{332}$ Moreover, the IACrtHR reached to the conclusion that consultation is an obligation that is a general principle of international law; 333 thus, failing to accomplish this right will lead to State's internationalaccountability. ${ }^{334}$

326. Case of the Kichwa Indigenous People of Sarayaku v. Ecuador, Merits and Reparations, Judgment Inter-American Court of Human Rights Series C No 245 (27 June 2012) para 186.

327. Ibid.

328. Op. cit., para 167.

329. Case of the Saramaka People v. Suriname, Merits, Reparations and Costs, Judgement, InterAmerican Court of Human Rights Series C No 172 (28 November 2007) para 133; see also Case of the Kichwa Indigenous People of Sarayaku v. Ecuador, Merits and Reparations, Judgment InterAmerican Court of Human Rights Series C No 245 (27 June 2012) para 177.

330. Case of the Saramaka People v. Suriname, Merits, Reparations and Costs, Judgement, InterAmerican Court of Human Rights Series C No 172 (28 November 2007) para 133; see also Case of the Kichwa Indigenous People of Sarayaku v. Ecuador, Merits and Reparations, Judgment InterAmerican Court of Human Rights Series C No 245 (27 June 2012) paras 201-203.

331. Case of the Saramaka People v. Suriname, Interpretation of the Judgement on Preliminary Objections, Merits, Reparations and Costs, Judgement, Inter-American Court of Human Rights Series C No 125 (12 August 2008), para 16.

332. Case of the Saramaka People v. Suriname, Merits, Reparations and Costs, Judgement, InterAmerican Court of Human Rights Series C No 172 (28 November 2007) paras 134-137.

333. Case of the Kichwa Indigenous People of Sarayaku v. Ecuador, Merits and Reparations, Judgment Inter-American Court of Human Rights Series C No 245 (27 June 2012) paras 159-164.

334. Op. cit., para 177. 
Therefore, States are forced to properly structure its institution to undertake suitable consultations processes; ${ }^{335}$ which are not delegable to third parties. ${ }^{336}$ States must control that negotiations will not reach an agreement that entails IP's rights detriment. ${ }^{337}$

From IP's perspective, participation should be entirely granted, and it should leave aside Eurocentric traditions. ${ }^{338}$ To achieve a proper participation, States must avoid discrimination within their societies, ${ }^{339}$ as IP have their participatory procedures and they use their own patterns throughout decision-making processes. ${ }^{340}$ The communitarian decision takes the due time to be constructed and, to reach an outcome, it is necessary the participation of the living peoples and their ancestors. ${ }^{341}$

Moreover, consultation and participation are a collective right; ${ }^{142}$ and, are directly attached to self-determination. ${ }^{343}$ IP are entitled to decide their resource management, through decision-making processes, which cannot be disregarded when an extraction project is planned to be carried out. Subsequently, IP's viewpoints are well considered in the Court's decisions; states must comply with the respect of IP's tradition in decision-making processes in order to obtain their prior consent to undertake an extractive activity within their territories.

The Kari-Oca Declaration has proved the need of IP to be consulted and to get their prior consent to carry out any project within their lands. ${ }^{344}$ Moreover, it stated that IP's should be aware of the project's information, and they should be plenty involved in its discussion; ${ }^{345}$ to this end, a formal agreement should be concluded. ${ }^{346}$

335. Op. cit., para 166.

336. Op. cit., para 187.

337. Op. cit., para 167.

338. ACOSTA (2013) p. 17.

339. Ibid.

340. DE SOUSA SANTOS (2010) pp. 13-14.

341. Op. cit., p. 122.

342. ACOSTA (2013) pp. 17, 118.

343. PORTAL OF CULTURE OF LATIN AMERICA AND THE CARIBBEAN, 'Kari-Oca Declaration and Indigenous Peoples' Earth Charter' (2016) www.lacult.unesco.org/doccult/listado. php?uid_ext=\&getipr=\&lg=2 accessed 26 March 2018 preamble, paras 7, 14, 20,62 .

344. Op. cit., para 61.

345. Ibid.

346. Op. cit., para 38. 
Projects without the consent of IP should be stopped. ${ }^{347}$ Furthermore, the Declaration expresses that failure to achieve this obligation may be considered as a crime against IP; which should be prosecuted in an international tribunal. ${ }^{348}$

In this respect, the IACrtHR has widely recognised IP's rights to participate, be consulted and to obtain their free, prior and informed consent before undertaking any extraction plan over their lands. It has concurred with IP's asserts contained in their beliefs and in the Kari-Oca Declaration.

\subsubsection{Benefit-sharing}

Benefit-sharing is contemplated in various international instruments regarding IP's rights. ${ }^{349}$ In this respect, the Court has considered that States shall 'reasonably shar[e] the benefits of [a] project with [IP]' 350 when the rights to use and enjoy their lands are threatened by proposed extraction projects. ${ }^{351}$ Furthermore, the exploitation of nontraditional resources might cause harm to those considered as traditional. Thus, both activities should require a benefit-sharing scheme. ${ }^{352}$

As well, the Court determined that benefit-sharing is a way to compensate IP from the exploitation of their lands and resources necessaries for their survival; ${ }^{353}$ therefore, States must ensure that IP, who live in a territory which will be probably exploited, receive a rational benefit from the earnings of such plan. ${ }^{354}$ The beneficiaries must be determined by IP themselves, rather than an arbitrary decision by the State. ${ }^{355}$

347. Op. cit., para 75.

348. Op. cit., para 61.

349. Convention Concerning Indigenous and Tribal Peoples in Independent Countries (ILO No 169) (1991) art. 15(2); United Nations Declaration on the Rights of Indigenous Peoples (2007) art. 32; American Declaration on the Rights of Indigenous Peoples (2016) arts. 13(2), 29(5).

350. Case of the Saramaka People v. Suriname, Merits, Reparations and Costs, Judgement, InterAmerican Court of Human Rights Series C No 172 (28 November 2007) para 138.

350. Case of the Saramaka People v. Suriname, Merits, Reparations and Costs, Judgement, InterAmerican Court of Human Rights Series C No 172 (28 November 2007) para 138.

351. Op. cit., para 139.

352. Op. cit., para 155.

353. Op. cit., para 140.

354. Op. cit., para 129.

355. Case of the Saramaka People v. Suriname, Interpretation of the Judgement on Preliminary Objections, Merits, Reparations and Costs, Judgement, Inter-American Court of Human Rights Series C No 125 (12 August 2008) para 25. 
IEL, through the CBD and Nagoya Protocol, entails various provisions that deal with IP's benefit-sharing. Both treaties cover IP's property rights and traditional knowledge; but focused on the use of biological resources. ${ }^{356}$ However, in this respect, the Kari-Oca Declaration expresses that the biodiversity is not inert, and it should not be conserved only for scientific or folkloric purposes. ${ }^{357}$

Benefit from economic activities on IP's lands is 'an essential element of the right to property; ${ }^{358}$ and it should centre in the reinforcement of IP's own decision regarding development and the protection of their lands. ${ }^{359}$ In this respect, the Kari-Oca Declaration has stated that when the State or the private sector want to use their lands, there should be a previous agreement and a compensation for its exploitation. ${ }^{360}$ Hence, for IP, benefit-sharing is also considered as part of a prior compensation agreement for the use of their territories and resources; they are aware of the social, economic and environmental reality.

Therefore, the Court has observed that IP's right to benefit-sharing is part of the right of compensation recognised in the American Convention; in the same sense, IP have considered the option of being compensated, through benefit-sharing, when a project is intended to be carried out in their lands. The connection exists between IP and the Court's awards.

356. Convention on Biological Diversity (1993) preamble.

357. PORTAL OF CULTURE OF LATIN AMERICA AND THE CARIBBEAN, 'Kari-Oca Declaration and Indigenous Peoples' Earth Charter' (2016) www.lacult.unesco.org/doccult/listado. php?uid_ext=\&getipr=\&lg=2 accessed 26 March 2018 para 59.

358. ANAYA and WILLIAMS (2001) p. 83.

359. Op. cit., p. 84.

360. PORTAL OF CUlTURE OF LATIN AMERICA AND THE CARIBBEAN, 'Kari-Oca Declaration and Indigenous Peoples' Earth Charter' (2016) www.lacult.unesco.org/doccult/listado. php?uid_ext=\&getipr=\&lg=2 accessed 26 March 2018 para 38. 


\subsubsection{Environmental and Social Impact Assessment (ESIA)}

IEL has widely recognised the need to undertake an Environmental Impact Assessment, whether through international instruments ${ }^{361}$ or case law. ${ }^{362}$ Regarding IP's issues, the ILO 169 establishes that States shall carry out studies to 'assess social, spiritual, cultural and environmental impact on them of planned development activities, ${ }^{363}$ with the participation of IP, and its conclusions must be considered as a fundamental criterion for the execution of any action. ${ }^{364}$ The IACrtHR also endorses the social aspect of the assessment, by stating that if it is not included, the State shall add it in at the time of its supervision. ${ }^{365}$

In this respect, the IACrtHR maintained that ESIA would serve to protect the relationship between IP, their lands, and their survival; ${ }^{366}$ it has defined that its purposes are to measure the possible damage on IP's lands and the community; ${ }^{367}$ to inform

361. Rio Declaration on Environment and Development (1992) principle 17; Convention on Environmental Impact Assessment in a Transboundary Context (1997); United Nations Framework Convention on Climate Change (1994) art. 4(1)(f); United Nations Convention on the Law of the Sea (1994) art. 206; Convention on Biological Diversity (1993) art. 14; United Nations General Assembly (1990a), para 11; International Law Commission Report (2001), art. 7.

362. Pulp Mills on the River Uruguay (Argentina v. Uruguay) (Judgment) [2010] ICJ Rep, p. 14 paras 203-266; Certain Activities Carried Out by Nicaragua in the Border Area (Costa Rica V. Nicaragua) And Construction of a Road in Costa Rica Along the San Juan River (Nicaragua V. Costa Rica), Judgement, ICJ Reports [2015], paras 101-105, 146-162; Responsibilities and Obligations of States with respect to Activities in the Area, Advisory Opinion, 1 February 2011, ITLOS Reports 2011, p. 10, paras 141-150.

363. Convention Concerning Indigenous and Tribal Peoples in Independent Countries (ILO No 169) (1991) art. 7(3).

364. Ibid.

365. Advisory Opinion on Environment and Human Right OC-23/17, Inter-American Court of Human Rights Series A No 23 (15 November 2017), para 164.

366. Convention Concerning Indigenous and Tribal Peoples in Independent Countries (ILO No 169) (1991) art. 7(3). See also Case of the Kichwa Indigenous People of Sarayaku v. Ecuador, Merits and Reparations, Judgment Inter-American Court of Human Rights Series C No 245 (27 June 2012) para 205.

367. Case of the Saramaka People v. Suriname, Interpretation of the Judgement on Preliminary Objections, Merits, Reparations and Costs, Judgement, Inter-American Court of Human Rights Series $C N^{o} 125$ (12 August 2008) para 40; see also Case of the Kichwa Indigenous People of Sarayaku v. Ecuador, Merits and Reparations, Judgment Inter-American Court of Human Rights Series C No 245 (27 June 2012) para 205. 
the population ${ }^{368}$ and warn them of potential environmental and health risks. ${ }^{369}$ The scope of an ESIA will entail the respect of IP's traditions and customs when dealing with their lands. ${ }^{370}$

States play a supervisory role; ${ }^{371}$ the Court has indicated that independent and specialized institutions should be requested to undertake these assessments..$^{372}$ In the Advisory Opinion on Human Rights and the Environment, the Court expressed that the obligation to carry out an EIA is for all the activities that may cause a significant environmental harm. ${ }^{373}$

Additionally, the ESIA will enhance the protection of the IP's rights of consultation and participation, ${ }^{374}$ as it will guarantee that IP are informed of the proposed plans in their territory, ${ }^{375}$ and by so, whether accept or not the proposed plan; $3^{376}$ which must be carried out prior their authorisation. ${ }^{377}$ Moreover, the duty of undertaking an ESIA should consider international standards and best practices. ${ }^{378}$ In this sense, the Court has invoked the Akwé: Kon Guidelines, which cover the content of

368. Case of the Saramaka People v. Suriname, Interpretation of the Judgement on Preliminary Objections, Merits, Reparations and Costs, Judgement, Inter-American Court of Human Rights Series C $N^{\circ} 125$ (12 August 2008) para 41.

369. Op. cit., para 40; see also Case of the Saramaka People v. Suriname, Merits, Reparations and Costs, Judgement, Inter-American Court of Human Rights Series C No 172 (28 November 2007) para 133.

370. Advisory Opinion on Environment and Human Right OC-23/17, Inter-American Court of Human Rights Series A No 23 (15 November 2017), para 169.

371. Op. cit., paras 163-164.

372. Case of the Saramaka People v. Suriname, Merits, Reparations and Costs, Judgement, InterAmerican Court of Human Rights Series C No 172 (28 November 2007) para 129.

373. Advisory Opinion on Environment and Human Right OC-23/17, Inter-American Court of Human Rights Series A No 23 (15 November 2017), para 157.

374. Op. cit., para 148. See also Advisory Opinion on Environment and Human Right OC- 23/17, Inter-American Court of Human Rights Series A No 23 (15 November 2017), paras 166-168.

375. Case of the Saramaka People v. Suriname, Interpretation of the Judgement on Preliminary Objections, Merits, Reparations and Costs, Judgement, Inter-American Court of Human Rights Series C $N^{o} 125$ (12 August 2008) para 41.

376. Op. cit., para 40.

377. Op. cit., para 41. See also Advisory Opinion on Environment and Human Right OC- 23/17, Inter-American Court of Human Rights Series A No 23 (15 November 2017), para 162.

378. Ibid. See also Advisory Opinion on Environment and Human Right OC-23/17, Inter- American Court of Human Rights Series A No 23 (15 November 2017), para 161. 
impact assessments related to plans that might affect IP, stating that it is 'one of the most comprehensive and used standards for ESIAs. ${ }^{379}$

Therefore, a suitable ESIA should have at least three requirements: a) the participation of IP in its creation; b) it should be carried out by a technically and competent institution, with State's supervision; and, c) it should consider the social, cultural, and spiritual impact that may have on IP. ${ }^{380}$ In this respect, the Kari-Oca Declaration does not contain an express provision about ESIA; yet, it can be stated that rights to participation, consultation and consent should need previous technical, social and environmental studies so IP could accept or not the proposed plan. ${ }^{381}$

The Court developed three important features from its judgements. First, the impact assessment required by the Court goes further than usual EIA, as the social matter was included within it; considering IP's ways of life within its content. Second, by remitting States to employ the Akwé: Kon Guidelines, ${ }^{382}$ the Court has determined the shape and content that an ESIA should comprise. Finally, it has gone beyond the standard of application of this principle in IEL, since the latter acknowledges the necessity of carrying out an EIA only when transboundary harm is likely to happen; ${ }^{383}$ while the ESIA is required when a proposed project will bring consequences to IP's territories within States' boundaries.

In this sense, the Court has applied international principles that were not expressly conceived by IP's worldview to guarantee the protection of their rights. The ESIA, which shall include the Akwé: Kon Guidelines content, reveals how the Court has taken the need for environmental and human rights sound standards seriously when IP's issues arise. The inclusion of these guidelines is a step forward to a proper

379. Op. cit., footnote 23.

380. Case of the Kichwa Indigenous People of Sarayaku v. Ecuador, Merits and Reparations, Judgment Inter-American Court of Human Rights Series C No 245 (27 June 2012) para 207.

381. PORTAL OF CULTURE OF LATIN AMERICA AND THE CARIBBEAN, 'Kari-Oca Declaration and Indigenous Peoples' Earth Charter' (2016) www.lacult.unesco.org/doccult/listado. php?uid_ext=\&getipr=\&lg=2 accessed 26 March 2018, para 35.

382. Decision Adopted by the Conference of the Parties to the Convention on Biological Diversity at its Seventh Meeting (2004).

383. Convention on Environmental Impact Assessment in a Transboundary Context (1997) art. 2(3); International Law Commission Report (2001) art. 1; Pulp Mills on the River Uruguay (Argentina v. Uruguay) (Judgment) [2010] ICJ Rep, p. 14 para. 204; Responsibilities and Obligations of States with respect to Activities in the Area, Advisory Opinion, 1 February 2011, ITLOS Reports 2011, p. 10 para. 148. See also BIRNIE et al. (2009) p. 167. 
protection of IP's rights, as one of their purposes is the integration of IP as a transversal subject in cultural, environmental and social impact assessments. ${ }^{384}$

\subsection{Beyond Human Rights}

As just seen, the IACrtHR made a great advance in defending and guarantying IP's environmental rights. The Advisory Opinion on Environment and Human Rights went beyond the usual way of looking at the right to a healthy environment. It intended to break the cycle of using existing human rights to protect somehow the environment per se, as it defined that this right is an autonomous one and it should be applicable regardless of the possible violations of other human rights.

The Court reflected that the core aspect of the right to a healthy environment is the protection of the environment for its own features. Moreover, it considered that the significance of environmental protection does not relate solely on its usefulness for the human being, rather it sustained that the environment shall be protected as its destruction might also affect all the living organisms that are part of the planet.

Therefore, it remains to be determined the scope given to the right to a healthy environment. It can be argued that the description given by the Court, on that subject, might entail to stand before it with a claim related to environmental harm, without the need of justify a direct violation of another human right, i.e. life, health, property, etc. Hence, possibly the theory of "greening" human rights can be abandoned and it will allow to establish a new paradigm related to the protection of any environment's component or organism.

As the Pachamama is indirectly referred throughout the decision, it can be argued, thus, that the reflections made by the IACrtHR can be certainly compared with IP's conception about the environment. Notwithstanding the legal nature of the right in question, as a human right, it is certainly conceived that international law is developing towards an eco-centric perception of the law, through the implications of an environmental discourse.

In this respect, it can be notable that, to certain point, IP's relationship and perception about the environment has influenced in the decisions made by the Court. The IACrtHR Advisory Opinion on Human Rights and the Environment entailed an interesting argument that may be considered as a strong linkage between IP's worldview and IACrtHR approaches. Indeed, a possible interpretation of this Advisory

384. Decision Adopted by the Conference of the Parties to the Convention on Biological Diversity at its Seventh Meeting (2004) para. 1-5. 
Opinion can be easily discussed in a different work. Nevertheless, it still to be seen how both States and the international community will react to this new approach when dealing with environmental rights, more precisely to nature's rights.

\section{Conclusion}

The definition of IP is a key aspect that has directed international law to determine who forms part of an IP's group, and by so, to entitle them with various set of rights. Self-determination, besides strengthening IP's own identity, has founded a basis to determine another group of individual and collective rights, specifically environmental rights.

Additionally, IP's ancestral traditions are based in a non-conventional cosmovision with respect to Western alternatives. It is evident that their knowledge has allowed them to survive throughout various threats that they have faced during the past centuries. As well, IP's environmental approach has defined a basis for some countries to take a new direction towards more environmentally sound policies, going even further than traditional ways of law-making in the sense of giving rights to the environment per se; establishing a new paradigm at least within state practice. This argument was appreciated by the IACrtHR Advisory Opinion on Human Rights and the Environment, which denotes a huge step towards a new debate at the international arena.

This conclusion will pose a new question: What if we go further and try to deeply merge IP's worldview, regarding the environment, into a Western-based, whether international or national, legal system?

As discussed, terms like sustainable development or environmental law are considered as part of Western thought; however, IP's worldview has demonstrated that both concepts have been used, mainly in America, since hundreds of years ago ${ }^{385}$ by local communities. Furthermore, the IACrtHR applied Western and nonWestern concepts to address IP's human and environmental rights; it has recognised the spiritual life of IP and how they interact with the land and the environment and how they can be, to some extent, merged in a Western legal construction.

It is evident that the IACrtHR has moved beyond the European Court of Human Rights since the application of human rights provisions, in terms of the environment, has a deeper ecological approach in the Americas. The gap established by the Court, while separating the right to a healthy environment from the rest of human rights, and, considering it as the basis for the enjoyment of other human rights, is of a tre-

385. CRAIG and PONCE (1995) p. 116. See also PORTAL OF CULTURE OF LATIN AMERICA AND THE CARIBBEAN, 'Kari-Oca Declaration and Indigenous Peoples' Earth Charter' (2016) www. lacult.unesco.org/doccult/listado.php?uid_ext=\&getipr=\&lg=2 accessed 26 March 2018, para 68. 
mendous weight. It might open the door for new claims that can be sustained in environmental protection, rather than have their basis on solely the protection of human rights.

IP's spiritual beliefs and traditions were recognised by the Inter-American Human Rights system through the acceptation of their right to cultural integrity. In addition, considering that, within IP's culture, the Pachamama, Gaia or Mother Earth has its own rights; then, regarding international law, it should not be a hard work to generate a paradigm shift while dealing with nature's rights. The question will remain open until the IACrtHR (or any other international tribunal) is asked to consider a proceeding regarding this matter, and how it will be approached.

Therefore, a step forward to deal with international and national environmental issues will be the inclusion of the correspondent IP's traditions, by recognising rights to nature, and by the direct application of human rights standards.

\section{Bibliography}

ACOSTA, Alberto (2013) El Buen Vivir: Sumak Kawsay, una oportunidad para imaginar otro mundo (Barcelona, Icaira).

Additional Protocol to the American Convention on Human Rights in the Area of Economic, Social and Cultural Rights (Protocol of San Salvador) (adopted 17 November 1988, entered into force 16 November 1999) OAS Treaty Series № 69 (1988).

Advisory Opinion on Environment and Human Right OC-23/17, Inter-American Court of Human Rights Series A No 23 (15 November 2017), para 62.

African Charter on Human and Peoples' Rights (adopted 27 June 1981, entered into force 21 October 1986) (1982) 21 ILM 58.

Agreement relating to the International Convention for regulating the police of the North Sea Fisheries (adopted o6 May 1882, entered into force 15 May 1884) 31 UNTS 145 .

American Convention on Human Rights (adopted 21 November 1969, entered into force 18 July 1978) 1144 UNTS 123.

American Declaration on the Rights of Indigenous Peoples, OAS Res 2888 adopted by the third plenary session (15 June 2016) (XLVI-O/16).

ANAYA, James (1993) 'A contemporary definition of the international norm of selfdetermination.' In Transnational Law \& Contemporary Problems 3(1), pp. 131-164.

ANAYA, James (1999) 'Environmentalism, human rights and indigenous peoples: a tales of converging and diverging interests.' In Buffalo Environmental Law Journal 7(1-2), pp. 1-13. 
ANAYA, James (2004) Indigenous Peoples in International Law (2nd edn, Oxford University Press).

ANAYA, James and WILLIAMS, Robert (2001) 'The Protection of Indigenous Peoples' Rights over Lands and Natural Resources Under the Inter-American Human Rights System.' In Harvard Human Rights Journal 14 pp. 33-86.

ANDERSON, Michael (1996) "Human Rights Approaches to Environmental Protection: An Overview”. In BOYLE, Michael and ANDERSON, Michael (eds.), Human Rights Approaches to Environmental Protection (Oxford University Press).

ANTON, Donald and SHELTON, Dinah (eds.) (2011), Environmental Protection and Human Rights (Cambridge University Press).

BARELLI, Mauro (2010) 'The Interplay between Global and Regional Human Rights Systems in the Construction of the Indigenous Rights Regime.' In Human Rights Quarterly 32(4), pp. 951-979.

BARSH, Russel (2008) “Indigenous Peoples”. In BODANSKY, Daniel et al. (eds.), The Oxford Handbook of International Environmental Law (Oxford University Press).

BEDÓN, René (2016) 'Contenido y Aplicación de los Derechos de la Naturaleza. In Ius Humani: Revista de Derecho 5(1), pp. 133-148.

Behring Sea Fur Seals Arbitration, Moore, 1 Int Arb Awards (1898) 755, repr in 1 IELR (1999).

BEYERLIN, Ulrich and MARAUHN, Thilo (2011) International Environmental Law (Hart Publishing).

BIRNIE, Patricia et al (2009), International Law and the Environment (3rd edn, Oxford University Press).

BODANSKY, Daniel (2001) The Art and Craft of International Environmental Law (Harvard University Press).

BODANSKY, Daniel et al. (2008), "International Environmental Law: Mapping the Field". In BODANSKY, Daniel et al. (eds), The Oxford Handbook of International Environmental Law (Oxford University Press).

BOYLE, Alan (1996) "The Role of International Human Rights Law in the Protection of the Environment". In BoYLE, Alan and ANDERson, Michael (eds.) Human Rights Approaches to Environmental Protection (Oxford, Oxford University Press).

BOYLE, Alan (2008a) "Human Rights or Environmental Rights? A Reassessment". In Fordham Environmental Law Review 18(3), pp. 471-511. 
BOYLE, Alan (2008b): "Relationship Between International Environmental Law and Other Branches of International Law”. In BODANSKY, Daniel et al (eds.) The Oxford Handbook of International Environmental Law (Oxford, Oxford University Press).

BOYLE, Alan (2012) “Human Rights and the Environment: Where Next?". In The European Journal of International Law, 23(3), pp. 613-642.

BOYLE, Alan and ANDERSON, Michael (eds.) (1996): Human Rights Approaches to Environmental Protection (Oxford, Oxford University Press).

BOYLE, Alan and CHINKIN, Christine (2007): The Making of International Law (Oxford, Oxford University Press).

BOYLE, Alan and FREESTONE, David (eds.) (1999): "International Law and Sustainable Development: Past Achievements and Future Challenges" (Oxford, Oxford University Press).

Budayeva and others $v$ Russian Federation, Merits and just satisfaction, App No 15339/o2, (2014) 59 EHRR 2, 2oth March 2008, European Court of Human Rights.

BURGER, Julian (2011) “The UN Declaration on the Rights of Indigenous Peoples: From Advocacy to Implementation". In ALLEN, Stephen and XANTHAKI, Alexandra (eds.), Reflections on the UN Declaration on the Rights of Indigenous Peoples (Hart Publishing).

Case of Kawas-Fernández v. Honduras, Merits, Reparations and Costs, Judgement, Inter-American Court of Human Rights Series C No 196 (3 April 2009), para 148.

Case of the Kichwa Indigenous People of Sarayaku v. Ecuador, Merits and Reparations, Judgment Inter-American Court of Human Rights Series C No 245 (27 June 2012).

Case of the Mayagna (Sumo) Awas Tingni Community v. Nicaragua, Merits, Reparations and Costs, Judgement, Inter-American Court of Human Rights Series C No 79 (31 January 2001).

Case of the Saramaka People v. Suriname, Interpretation of the Judgement on Preliminary Objections, Merits, Reparations and Costs, Judgement, InterAmerican Court of Human Rights Series C No 125 (12 August 2008).

Case of the Saramaka People v. Suriname, Merits, Reparations and Costs, Judgement, Inter-American Court of Human Rights Series C No 172 (28 November 2007).

Case of the Sawhoyamaxa Indigenous Community v. Paraguay, Merits, Reparations and Costs, Judgment Inter-American Court of Human Rights Series C No 146 (29 March 2006).

Case of the Xákmok Kásek Indigenous Community v. Paraguay, Merits, Reparations and Costs, Judgement, Inter-American Court of Human Rights Series C No 214 (24. August 2010). 
Case of the Yakye Axa Indigenous Community v. Paraguay, Merits, Reparations and Costs, Judgement, Inter-American Court of Human Rights Series C No 125 (17 June 2005)

CASSESE, Antonio (1995) Self-Determination of Peoples: A Legal Reappraisal (Cambridge University Press).

Certain Activities Carried Out by Nicaragua in the Border Area (Costa Rica V. Nicaragua) And Construction of a Road in Costa Rica Along the San Juan River (Nicaragua V. Costa Rica), Judgement, ICJ Reports [2015].

Constitution of the Republic of Ecuador.

Convention Concerning Indigenous and Tribal Peoples in Independent Countries (ILO No 169) (adopted 27 June 1989, entered into force 05 September 1991) 72 ILO Official Bull. 59.

Convention Concerning the Conservation of Migratory Birds and Their Environment (United States of America - Union of Soviet Socialist Republic) (19 November 1976) 29 UST 4647.

Convention concerning the Protection and Integration of Indigenous and Other Tribal and Semi-Tribal Populations in Independent Countries (ILO No 107) (adopted 26 June 1957, entered into force o2 June 1959) 328 UNTS 247.

Convention for the Preservation and Protection of Fur Seals (adopted o7 July 1911, entered into force 15 December 1911) 104 BFSP 175.

Convention for the Preservation of the Halibut Fishing of the Northern Pacific (adopted 02 March 1923, entered into force 21 October 1924) 32 LNTS 94.

Convention for the Preservation of Wild Animals, Birds and Fish in Africa (adopted 19 May 1900), 94 British and Foreign State Papers 715.

Convention for the Protection of Migratory Birds and Birds in Danger of Extinction and Their Environment (United States of America - Japan) (o4 March 1972) 25 UST 3329.

Convention for the Protection of Migratory Birds in the United States and Canada (United States of America - Canada) (16 May 1916) 39 Stat. 1702.

Convention for the Regulation of Whaling (adopted 24. September 1931, entered into force 16 January 1935) 155 LNTS 349.

Convention on Access to Information, Public Participation in Decision-Making and Access to Justice in Environmental Matters (adopted 28 June 1998, entered into force 30 October 2001) 2161 UNTS 4.47.

Convention on Biological Diversity (adopted 05 June 1992, entered into force 29 December 1993) 31 ILM 818. 
Convention on Biological Diversity 'List of Parties' (cbd.int, 2017) www.cbd.int/ information/parties.shtml accessed 26 March 2018.

Convention on Environmental Impact Assessment in a Transboundary Context (adopted 25 February 1991, entered into force 10 September 1997) 30 ILM 802.

Convention on International Trade in Endangered Species of Wild Fauna and Flora (adopted 03 March 1973, entered into force 01 July 1975) 993 UNTS 243.

Convention on the Conservation of Migratory Species of Wild Animals (adopted 23 June 1979, entered into force o1 November 1983) 1651 UNTS 333.

Convention on the Preservation of Flora and Fauna in Their Natural State (adopted o8 November 1933, entered into force 14 January 1936), United Kingdom Treaty Series $\mathrm{N}^{\circ} 27$ (1936).

Convention on the Rights of the Child (adopted 20 November 1989, entered into force o2 September 1990) 1577 UNTS 3.

Convention on Wetlands of International Importance especially as Waterfowl Habitat (adopted o2 February 1971, entered into force 21 December 1975) 996 UNTS 245.

Corte Constitucional [C.C.] [Constitutional Court], noviembre 10, 2016, Sentencia T-622/16 (Colom.). (corteconstitucional.gov.co 2017) www.corteconstitucional. gov.co/relatoria/2016/t-622-16.htm accessed 26 March 2018.

Corte Suprema de Justicia [CSJ] [Supreme Court] Sal. Civ. julio 26, 2017, L.A. Tolosa, Radicación 17001-22-13-000-2017-00468-02 (Colom.).

COTTERELL, Arthur (2017) A Dictionary of World Mythology (Oxford University Press 2003) DOI:10.1093/acref/9780192177476.001.0001, accessed 26 March 2018.

CRAIG, Donna and PONCE, Diana (1995) “Indigenous Peoples' Rights and Environmental Law”. In LIN, Sun and KURUKULASURIYA, Lal (eds.), UNEP's New Way Forward: Environmental Law and Sustainable Development (United Nations Environmental Programme).

CRAWFORD, James (2006) The Creation of States in International Law (2nd edn, Oxford University Press).

CRAWFORD, James (2012) Brownlie's Principles of Public International Law (8th edn, Oxford University Press).

CRUZ RODRÍGUEZ, Edwin (2014) "Del derecho ambiental a los derechos de la naturaleza: sobre la necesidad del diálogo intercultural". In Jurídicas 11(1), pp. 95-116.

CULLET, Philippe (2016) "Human Rights and Climate Change: Broadening the Right to Environment”. In Carlarne, Cinnamon et al. (eds.), The Oxford Handbook of International Climate Change Law (Oxford University Press). 
CULLINAN, Cormac (2002) Wild Law: A Manifesto for Earth Justice (Green Books). DE OLIVEIRA MAZZUOLI, Valerio and De FARIA MOREIRA TEIXEIRA, Gustavo (2015) 'Protección jurídica del medio ambiente en la jurisprudencia de la Corte Interamericana de Derechos Humanos.' In Revista Internacional de Derechos Humanos 5(5), pp. 19-50.

DE SOUSA SANTOS, Boaventura (2010) Refundación del Estado en América Latina: Perspectivas desde una epistemología del Sur (Instituto Internacional de Derecho y Sociedad).

Decision Adopted by the Conference of the Parties to the Convention on Biological Diversity at its Seventh Meeting, held at Kuala Lumpur from 9-20 and 27 February 2004, Article 8(j) and related provisions, Decision VII/16, UN Doc UNEP/CBD/ COP/DEC/VII/16 (13 April 2004).

Decision Adopted by the Conference of the Parties to the Convention on Biological Diversity at its Twelfth Meeting, held at Pyeongchang, from 6 to 17 October 2014, Article $8(\mathrm{j})$ and related provisions, Decision XII/12, UN Doc UNEP/ CBD/COP/ $\mathrm{DEC} / \mathrm{XII} / 12$ (13 October 2014).

Declaration of the United Nations Conference on the Human Environment (adopted 16 June 1972) 11 ILM 1416.

Declaration on the Rights of Persons Belonging to National or Ethnic, Religious and Linguistic Minorities (adopted 18 December 1992), UNGA Res 47/135. East Timor (Portugal v. Australia) (Judgement) [1995] ICJ Rep, p. 90.

EBBESSON, Jonas (2008) "Public Participation". In BODANSKY, Daniel et al. (eds.), The Oxford Handbook of International Environmental Law (Oxford University Press).

Ecosoc 'Establishment of a Permanent Forum on Indigenous Issues' (28 July 200o) $\mathrm{UN}$ Doc E/RES/200o/22.

Ecosoc 'Report of the Working Group on Indigenous Populations on its fourteenth session', held at Geneva from 29 July to 2 August 1996, Discrimination Against Indigenous Peoples, (16 August 1996) UN Doc E/CN.4/Sub.2/1996/21.

Ecosoc 'Review of Further Developments in Fields with which the Sub-Commission has been concerned, Human Rights and the Environment, Final report prepared by Mrs. Fatma Zohra Ksentini, Special Rapporteur' (o6 July 1994) UN Doc E/ CN.4/Sub.2/1994/9.

Ecosoc 'Working Paper by the Chairperson-Rapporteur, Mrs. Erica-Irene A. Daes, on the concept of "indigenous people" (10 June 1996) UN Doc E/CN.4/ Sub.2/ AC.4/1996/2. 
ERUETI, Andrew (2011) The International Labour Organization and the Internationalisation of the Concept of Indigenous Peoples. In ALLEN Stephen and XANTHAKI Alexandra (eds.), Reflections on the UN Declaration on the Rights of Indigenous Peoples (Hart Publishing).

European Convention for the Protection of Human Rights and Fundamental Freedoms as amended by Protocols Nos 11 and 14 (adopted 4 November 1950, entered into force 3 September 1953) ETS 5.

Fadeyeva v Russian Federation, Merits and just satisfaction, App № 55723/oo, (2007) 45 EHRR 10, 9th June 2005, European Court of Human Rights.

FIRESTONE, Jeremy et al. (2005), 'Cultural Diversity, Human Rights, and the Emergence of Indigenous Peoples in International and Comparative Environmental Law. In American University International Law Review 20(2), pp. 219-292.

Gabcikovo-Nagymaros Project (Hungary v Slovakia) (Judgment) [1997] ICJ Rep, p. 7.

GILBERT, Jérémie (2011) 'Indigenous Peoples' Human Rights in Africa: The Pragmatic Revolution of the African Commission on Human and Peoples' Rights.' In International and Comparative Law Quarterly 6o(1), pp. 245-270.

GILLESPLE, Alexander (2001a) The Illusion of Progress: Unsustainable Development in International Law and Policy (Earthscan Publications).

GILLESPIE, Alexander (2001b) “Aboriginal Subsistence Whaling: A Critique of the Inter-Relationship between International Law and the International Whaling Commission". En Colorado Journal of International Environmental Law and Policy 12(1), pp. 77-139.

GILLESPIE, Alexander (2014) International Environmental Law, Policy and Ethics (2nd edn, Oxford University Press).

GUDYNAS, Eduardo (2010) "La Senda Biocéntrica: Valores Intrinsecos, Derechos de la Naturaleza y Justicia Ecológica”. In Tabula Rasa 13(1), pp. 45-71.

Guerra and others v Italy, Admissibility, merits and just satisfaction, App No 14967/89, Case No 116/1996/735/932, (1998) 26 EHRR 357, 19th February 1998, European Court of Human Rights.

GUHA, Ramachandra (20oo) Environmentalism: A Global History (Longman World History Series).

HANNUM, Hurst (1990) Autonomy, Sovereignty, and Self-Determination: The Accommodations of Conflicting Rights (University of Pennsylvania Press).

HECTOR GROSS Espiell, The Right to Self-Determination: Implementation of United Nations Resolutions, UN Doc. E/CN.4/Sub.2/405/Rev.1 (New York 1980).

HEY, Ellen (2003) 'Sustainable Development, Normative Development and the Legitimacy of Decision-making.' In Netherlands Yearbook of International Law 34(1), pp. 3-53. 
HIGGINS, Rosalyn (1994) Problems \& Process: International Law and How We Use it (Oxford University Press).

HIGGINS, Rosalyn (2009) Themes and Theories (Oxford University Press).

HILLIER, Timothy (1999) Principles of Public International Law (2nd edn, Cavendish Publishing Limited).

HITCHCOCK, Robert (1994) 'International Human Rights, the Environment, and Indigenous Peoples'. In Colorado Journal of International Environmental Law $\mathcal{E}$ Policy 5(1) pp. 1-22.

Inter-American Commission on Human Rights 'Report on the Situation of Human Rights in Ecuador' (24 April 1997) Doc. OEA/Ser.L/V/II.96 Doc. 10 rev. 1 www. cidh.org/countryrep/ecuador-eng/Chaper-8.htm accessed 26 March 2018.

Inter-American Commission on Human Rights, 'Indigenous and Tribal Peoples' Rights over their Ancestral Lands and Natural Resources, Norms and Jurisprudence of the Inter-American Human Rights System' (30 December 2009) Doc. OEA/Ser.L/V/II, Doc. 56/o9., paras 274-275, 277.

Inter-American Commission on Human Rights, 'The Human Rights Situation of the Indigenous People in the Americas,' (20 October 200o) Doc. OEA/Ser.L/V/ II.108, Doc. 62.

Intercontinental Cry 'Indigenous Peoples \& Nations in IC' (intercontinentalcry. org, 2017) https://intercontinentalcry.org/indigenous-peoples accessed 26 March 2018.

International Convention for the Regulation of Whaling (adopted 02 December 1946, entered into force 10 November 1948) 161 UNTS 72.

International Covenant on Civil and Political Rights (adopted 16 December 1966, entered into force 23 March 1976) 999 UNTS 171.

International Covenant on Economic, Social and Cultural Rights (adopted 16 December 1966, entered into force o3 January 1976) 993 UNTS 3.

International Human Rights Instruments, 'Compilation of General Comments and General Recommendations Adopted by Human Rights Treaty Bodies' General Recommendations Adopted by the Committee on the Elimination of Racial Discrimination, XXIII Rights of indigenous peoples [1997] (12 May 2003) UN Doc HRI/ GEN/1/Rev.6.

INTERNATIONAL LABOUR OFFICE (2009), Indigenous E Tribal Peoples' Rights in Practice (International Labour Organization).

INTERNATIONAL LABOUR OFFICE (2013), Understanding the Indigenous and Tribal People Convention, 1989 ( $N^{o}$ 169) Handbook for ILO Tripartite Constituents (International Labour Organization). 
International Labour Office 'Ratifications of $\mathrm{C} 169$ - Indigenous and Tribal Peoples Convention, 1989 ( $\mathrm{N}^{\circ}$ 169)' (ilo.org, 2017) www.ilo.org/dyn/normlex/en/f? p=NO RMLEXPUB:1130o:o::NO::P1130o_INSTRUMENT_ID:312314 accessed 26 March 2018.

International Law Commission Report (2001), Draft Articles on Prevention of Transboundary Harm from Hazardous Activities, with commentaries GAOR A/56/10.

International Law Commission Report (2001), Draft Articles on Responsibility of States for Internationally Wrongful Acts, with commentaries GAOR A/56/49.

International Whaling Commission 'Aboriginal Subsistence Whaling Sub-committee' (iwc.int, 2017) https://iwc.int/aboriginal-subsistence-whaling-sub-committee accessed 26 March 2018.

Iron Rhine Arbitration (The Kingdom of Belgium $v$ The Kingdom of Netherlands) (2005) PCA.

KINGSBURY, Benedict (1998) “"Indigenous Peoples" in International Law: A Constructivist Approach to the Asian Controversy". In American Journal of International Law 92(3), pp. 414-457.

KINGSBUSRY, Benedict (1999) "The Applicability of the International Legal Concept of "Indigenous Peoples". In BAUER, Joanne and BELL, Daniel (eds.), The East Asian Challenge for Human Rights (Cambridge University Press).

KINGSBURY, Benedict (2001) "Reconciling five competing conceptual structures of indigenous peoples' claims in international and comparative law". In New York University Journal of International Law and Politics, 4(1), pp. 189-252.

KINGSBURY, Benedict (2011) "Indigenous Peoples, Rights, and the Environment." In ANtoN Donald and SheLtoN Dinah (eds), Environmental Protection and Human Rights (Cambridge University Press 2011).

Lake Lanoux Arbitration (France v. Spain) (1957) 12 R.I.A.A. 281.

Legal Consequences of the Construction of a Wall in the Occupied Palestinian Territory (Advisory Opinion) [2004] ICJ Rep, p. 136. Legality of the Threat or Use of Nuclear Weapons (Advisory Opinion) [1996] ICJ Rep, p. 226

LEUPRECHT, Peter (2001) "Minority Rights Revisited: New Glimpses of an Old Issue”. In ALSTON, Philip (ed.), Peoples' Rights (Oxford University Press).

López Ostra v Spain, Merits and just satisfaction, App № 16798/90, A/303-C, (1995) 20 EHRR 277, 9th December 1994, European Court of Human Rights.

LOVELOCK, James (1991) Gaia: The practical science of planetary medicine (Gaia Books Limited). 
LOVELOCK, James (2006) The Revenge of Gaia: Why the Earth is Fighting Back and How We Can Still Save Humanity (Penguin Group).

MAGRAW, Daniel and Hawke, Lisa (2008) "Sustainable Development". In BODANSKY, Daniel et al (eds), The Oxford Handbook of International Environmental Law (Oxford University Press).

Maya Indigenous Communities of the Toledo District (Belize), Merits, Inter-American Commission on Human Rights, Report No 40/o4, case 12.053 (12 October 2004).

MCCORQUODALE, Robert (1994) 'Self-Determination: A Human Rights Approach'. In International and Comparative Law Quarterly 43(1), pp. 857-885.

MERRILLS, John (2008) “Environmental Rights". In BODANSKY, Daniel et al. (eds.), The Oxford Handbook of International Environmental Law (Oxford University Press).

MICKELSON, Karin (2001) 'South, North, International Environmental Law, and International Environmental Lawyers. In Yearbook of International Environmental Law 11(1), pp. 52-81.

MILLER, Shawn (2007) An Environmental History of Latin America (Cambridge University Press).

Minority Schools in Albania (Advisory Opinion) [1935] PCIJ Rep Series A/B No 64. Montreal Protocol on Substances that Deplete the Ozone Layer (adopted 16 September 1987, entered into force o1 January 1989) 1522 UNTS 3.

MORGERA, Elisa and TSIOUMANI, Elsa (2011) 'Yesterday, Today and Tomorrow: Looking Afresh at the Convention on Biological Diversity.' In Yearbook of International Environmental Law 21(1), pp. 3-40.

MORGERA, Elisa et al. (2013a) The 2010 Nagoya Protocol on Access and Benefitsharing in Perspective: Implications for International Law and Implementation Challenges (Martinus Nijhoff).

MORGERA, Elisa et al. (2013b), Unravelling the Nagoya Protocol: A Commentary on the Nagoya Protocol on Access and Benefit-sharing to the Convention on Biological Diversity (Martinus Nijhoff).

Nagoya Protocol on Access to Genetic Resources and the Fair and Equitable Sharing of Benefits Arising from Their Utilization to the Convention on Biological Diversity (adopted 29 October 2010, entered into force 12 October 2014) UN Doc UNEP/ $\mathrm{CBD} / \mathrm{COP} / 10 / 27$.

New Zealand Legislation 'Te Awa Tupua (Whanganui River Claims Settlement) Act 2017' (legislation.govt.nz, 2017) www.legislation.govt.nz/act/public/2017/ooo7/latest/whole.html accessed 26 March 2018. 
ODELLO, Marco (2012) 'Indigenous peoples' rights and cultural identity in the inter-American context.' In The International Journal of Human Rights 16(1), pp. 25-50.

OhchR, 'Analytical Study on the Relationship Between Human Rights and the Environment' (16 December 2011) UN Doc A/HRC/19/34.

On the Conservation of Antarctic Marine Living Resources (adopted 20 May 1980, entered into force o7 April 1982) 1329 UNTS 48.

Öneryıldız v Turkey, Merits and just satisfaction, App No 48939/99, (2005) 41 EHRR 20, 3oth November 2004, European Court of Human Rights.

Oxford English Dictionary, 'Gaia' (oed.com, 2017) www.oed.com.ezproxy.is.ed. ac.uk/ view/Entry/248779?redirectedFrom=gaia\#/eid accessed 26 March 2018.

Paris Agreement (adopted 12 December 2015, entered into force 04. November 2016) UN Doc FCCC/CP/2015/10/Add.1.

PHILLIPS, James (2015) 'The rights of indigenous peoples under international law.In Global Bioethics 26(2), pp. 120-127.

PITTY, Roderic (2001) 'Indigenous Peoples, Self-determination and International Law. In The International Journal of Human Rights 5(4), pp. 44-71.

Political Constitution of Bolivia.

Portal of Culture of Latin America and the Caribbean, 'Kari-Oca Declaration and Indigenous Peoples' Earth Charter' (lacult.unesco.org, 2016) www.lacult. unesco. org/doccult/listado.php?uid_ext=\&getipr=\&lg=2\& accessed 26 March 2018.

Protocol on Environmental Protection to the Antarctic Treaty (adopted o4 October 1991, entered into force 14 January 1998) (1991) 30 ILM 1455.

Pulp Mills on the River Uruguay (Argentina v. Uruguay) (Judgment) [2010] ICJ Rep, p. 14.

REDGWELL, Catherine (1996) "Life, the Universe and Everything: A critique of Anthropocentric Rights". In BoYLE, Alan and ANDERson, Michael (eds.), Human Rights Approaches to Environmental Protection (Oxford University Press).

REID, Emily (2015) Balancing Human Rights, Environmental Protection and International Trade: Lessons from the EU Experience (Hart Publishing).

Responsibilities and Obligations of States with respect to Activities in the Area, Advisory Opinion, 1 February 2011, ITLOS Reports 2011, p. 10.

RICHARDSON, Benjamin (2001) "Indigenous Peoples, International Law and Sustainability”. In Review of European Community \& International Environmental Law 10(1), pp. 1-12. 
RICHARDSON, Benjamin and CRAIG, Donna (2006) "Indigenous Peoples, Law and the Environment". In RICHARDSON, Benjamin and WOOD, Stepan (eds.), Environmental Law for Sustainability (Hart Publishing).

Rio Declaration on Environment and Development (adopted 13 June 1992) 31 ILM 874.

RODRIGUEZ-RIVERA, Luis (2001) 'Is the Human Right to Environment Recognized Under International Law? It depends on the source.' In Colorado Journal of International Environmental Law and Policy 12(1), pp. 1-45.

SAHTOURIS, Elisabet (200o) EarthDance: Living Systems in Evolution (iUniversity Press).

SAND, Peter (2008) "The Evolution of International Environmental Law". In BODANSKY, Daniel et al. (eds.), The Oxford Handbook of International Environmental Law (Oxford University Press).

SANDS, Philippe (2008) "Environmental Protection in the Twenty-first Century: Sustainable Development and International Law". In Revesz, Richard et al. (eds.), Environmental Law, the Economy, and Sustainable Development (Cambridge University Press).

SANDS, Philippe (2012) Principles of International Environmental Law (2nd edn, Cambridge University Press).

SARANTI, Vasiliki (2012) 'International Justice and Protection of Indigenous PeoplesThe Case-Law of the Inter-American Court of Human Rights.' In US-China Law Review 9(5), pp. 427-456.

SECRETARÍA NACIONAL SE PLANIFICACIÓN Y DESARROLLO (SENPLADES) (2010) Los Nuevos Retos de América Latina: Socialismo y Sumak Kawsay.

SHELTON, Dinah (1991) "Human Rights, Environmental Rights, and the Right to Environment”. In Stanford Journal of International Law 28(1), pp. 103-138.

SHELTON, Dinah (2011) "Self-Determination in Regional Human Rights Law: From Kosovo to Cameroon". In American Journal of International Law 105(1), pp. $60-81$.

SHUTKIN, William (1991) 'International Human Rights Law and the Earth: The Protection of Indigenous Peoples and the Environment.' In Virginia Journal of International Law 31(3), pp. 479-511.

SIEGFRIED, Wiessner (1999) 'Rights and Status of Indigenous Peoples: A Global Comparative and International Legal Analysis.' In Harvard Human Rights Journal 12(1), pp. 57-128.

Social and Economic Rights Action Center (SERAC) and Center for Economic and Social Rights (CESR) v Nigeria, African Commission on Human and Peoples' Rights, Communication 155/96 (2002). 
Statute of the International Court of Justice (adopted 26 June 1945, entered into force 24. October 1945) 59 Stat. 1031.

SUMMERS, James (2013) "The internal and external aspects of self-determination reconsidered". In FRENCH, Duncan (ed.), Statehood and Self-Determination: Reconciling Tradition and Modernity in International Law (Cambridge University Press).

Taşkin and others $v$ Turkey, Merits and just satisfaction, App No 46117/99, (2006) 42 EHRR 50, 10th November 2004, European Court of Human Rights.

Tătar and Tătar v Romania, Merits and just satisfaction, App No67021/01, 27th January 2009, European Court of Human Rights.

TAYLOR, Prudence (1998) 'From Environmental to Ecological Human Rights: A New Dynamic in International Law?' In Georgetown International Environmental Law Review 10(2), pp. 309-397.

The Barcelona Traction, Light and Power Company, Limited (Belgium v Spain) (Judgment) [1970] ICJ Rep, p. 3.

The Guardian 'Ganges and Yamuna rivers granted same legal rights as human beings' (theguardian.com, 2017) <https://www.theguardian.com/world/2017/mar/21/ ganges-and-yamuna-rivers-granted-same-legal-rights-as-human-beings $>$ accessed 26 March 2018.

THORNBERRY, Patrick (2002) Indigenous Peoples and Human Rights (Manchester Scholarship Online).

Trail Smelter Case (United States of America v Canada) (1941) 35 AJIL 684.

TSOSIE, Rebecca (2007) 'Indigenous people and environmental justice: the impact of climate change'. In University of Colorado Law Review 78(4), pp. 1625-1677.

UNCESCR 'Consideration of Reports submitted by States Parties under Articles 16 and 17 of the Covenant, Concluding Observations on Russian Federation (Thirtyfirst session)' (12 December 2003) UN Doc E/C.12/1/Add.94.

UNCHR Fifty-third session 'Prevention of Discrimination and Protection of Indigenous Peoples and Minorities. Indigenous peoples and their relationship to land. Final working paper prepared by the Special Rapporteur, Mrs. Erica-Irene A. Daes' (11 June 2001) UN Doc E/CN.4/Sub.2/2001/21.

UNHRC 'Report of the OHCHR on the Relationship Between Climate Change and Human Rights' (15 January 2009) UN Doc A/HRC/10/61.

UNITED NATIONS (2009), State of the World's Indigenous Peoples (United Nations). United Nations 'Report of the United Nations Conference on the Human Environment' (o5-16 June 1972) UN Doc A/CONF.48/14/Rev.1. 
United Nations Charter (adopted 26 June 1945, entered into force 24. October 1945) 59 Stat. 1031.

United Nations Convention on the Law of the Sea (adopted 10 December 1982, entered into force 16 November 1994) 1833 UNTS 3.

United Nations Declaration on the Rights of Indigenous Peoples (12 September 2007) UN Doc A/61/L.67/Annex.

UNITED NATIONS ECONOMIC COMMISSION (2014), The Aarhus Convention: An implementation guide (2nd edn, United Nations)

United Nations Economic Commission for Latin America and the Caribbean (2018) https://repositorio.cepal.org/bitstream/handle/11362/39051/37/S1800064_en.pdf accessed 14, March 2018.

United Nations Economic Commission for Latin America and the Caribbean (2018) https://negociacionp1o.cepal.org/9/en/news/america-latina-caribe-adopta suprimer-acuerdo-regional-vinculante-la-proteccion-derechos accessed 14March 2018.

United Nations Educational, Scientific and Cultural Organization Convention on the Protection and Promotion of the Diversity of Cultural Expressions (Adopted by the 33rd Session of the General Conference of UNESCO in Paris, 21 October 2005) http://unesdoc.unesco.org/images/o014/o01429/142919e.pdf accessed 26 March 2018.

United Nations Educational, Scientific and Cultural Organization Declaration of the Principles of International Cultural Cooperation, 'Records of the General Conference Fourteenth Session' (Paris, 1966) http://unesdoc.unesco.org/ images/o011/o01140/114048e.pdf\#page=82 accessed 26 March 2018.

United Nations Educational, Scientific and Cultural Organization Universal Declaration on Cultural Diversity (Adopted by the 31st Session of the General Conference of UNESCO in Paris, 2 November 2001).

United Nations Educational, Scientific and Cultural Organization, Mexico City Declaration on Cultural Policies, World Conference on Cultural Policies, (Mexico City, 26 July 6 August 1982) http://webarchive.unesco.org/20170204034755/ http://portal.unesco.org/culture/en/files/12762/11295421661mexico_en.pdf/ mexico_en.pdf accessed 26 March 2018.

United Nations Framework Convention on Climate Change, (adopted o9 May 1992, entered into force 21 March 1994) 1771 UNTS 107.

United Nations GAOR 46th Session, Agenda Item 21 (14 June 1992) UN Doc A/ Conf.151/26. 
United Nations General Assembly 'Need to ensure a healthy environment for the wellbeing of individuals' UNGA Res 45/94 (14 December 1990) UN Doc A/RES/45/94.

United Nations General Assembly Res 37/7 'World Charter for Nature' (28 October 1990) UN Doc A/RES/37/7.

United Nations Treaty Collection 'Convention on Access to Information, Public Participation in Decision-Making and Access to Justice in Environmental Matters' (treaties.un.org, 2017) https://treaties.un.org/Pages/ViewDetails. aspx?src=IND\&mtdsg_no=XXVII-13\&chapter=27\&clang=_en accessed 26 March 2018.

United States Import Prohibition of Certain Shrimp and Shrimp Products-Report of the Appellate Body (12 October 1998) WT/DS58/AB/R.

VERBEEK, Carol (2012) "Free, prior, informed consent: the key to self-determination: an analysis of the Kichwa People of Sarayaku v Ecuador". In American Indian Law Review 37(1) pp. 263-282.

VERMEYLEN, Saskia (2013) 'The Nagoya Protocol and customary law: the paradox of narratives in the law. In Law, Environment and Development Journal 9(2), pp. 185-201.

Vienna Convention on the Law of Treaties (adopted 23 May 1969, entered into force 27 January 1980) 1155 UNTS 331.

Western Sahara (Advisory Opinion) [1975] ICJ Rep, p. 12.

WILLIAMS, Robert (1990) 'Encounters on the Frontiers of International HumanRights Law Redefining the Terms of Indigenous Peoples Survival in the World' In Duke Law Journal 1(4), pp. 660-704.

WILSON, Richard and PERLIN, Jan (2003) 'The Inter-American Human Rights system: activities from late 2000 through October 2002.' In American University International Law Review 18(3), pp. 651-752.

World Conference on Human Rights, 'Vienna Declaration and Programme of Action' (25 June 1993) UN Doc A/CONF.157/23.

ZAFFARONI, Eugenio (2012) La Pachamama y el Humano (Ediciones Colihue). ZYBERI, Gentian (2009) 'Self-determination through the Lens of the International Court of Justice.' In Netherlands International Law Review 56, pp. 429-453. 